\title{
36. VEIN STRUCTURE AND ITS DEFORMATIONAL HISTORY IN THE SEDIMENTARY ROCKS OF THE MIDDLE AMERICA TRENCH SLOPE OFF GUATEMALA, DEEP SEA DRILLING PROJECT LEG 84 ${ }^{1}$
}

\author{
Yujiro Ogawa and Yuichiro Miyata, Department of Geology, Kyushu University ${ }^{2}$
}

\begin{abstract}
Vein structure and related small fractures in muddy sedimentary Oligocene to Miocene rocks of Sites 568 and 569 have been analyzed to study the deformation and tectonics of the Middle America Trench landward slope area off Guatemala. These veins are filled with fine, clayey materials and essentially developed as extensional fracture cleavages perpendicular to the minimum principal compressive stress axis. Three stages are recognized; early stage fractures parallel to bedding (probably caused by bedding parallel slip), abundant fractures highly oblique or perpendicular to bedding, and veins formed at various angles during tilting. Most of the veins show drag or rotation features, which mostly show downdip sliding and probably occurred during stages of large-scale folding related to faulting or draping of the middle Trench slope area. Veins are concentrated only in the middle part of the Trench landward slope of the late Oligocene to middle Miocene sections, where high sedimentation rates and possible normal faulting and folding caused by local uplift of the basement occurred. This may indicate that the veins required rapid sediment consolidation, which caused abnormal lithification.
\end{abstract}

\section{INTRODUCTION}

Leg 84 drilled nearly the same sites as Leg 67 in the Trench slope area off Guatemala, where considerable thicknesses of Trench slope sediments were recovered. "Vein structures" or simply "veins" have been reported both in Leg 67 muddy rocks at certain depths in the middle Trench slope area (Cowan, 1982) and now at Leg 84 sites, particularly Sites 568 and 569 (Figs. 1 and 2). The veins are subparallel planar structural discontinuities appearing as dark linear, curved, or braided traces.

The chief aim of this chapter is to describe the mode of occurrence of the vein structures together with the other postdepositional structures, to investigate the conditions and mechanisms necessary for their development, and finally to discuss the Trench landward slope tectonics. In Leg 84 , we were fortunate to take many good samples that contain more varieties of occurrence of vein structures than had been previously recognized. We have been successful in relating the stages of development of such structures to the Trench slope tectonics, but have not been able to work out the directions of tectonic stress axes responsible for the vein structures because of lack of core orientation.

\section{PROCEDURES OF TREATMENT OF VEIN STRUCTURES}

When the cores were cut on board, we carefully observed the cut surfaces to note the sedimentary structures as well as other post sedimentary or tectonic structures. On board ship, the three-dimensional configuration of the veins was sometimes described but not in every case. Most of the photographed and sketched figures in this chapter are apparent two-dimensional traces of structures. Where the vein structures were developed, samples of sufficient size were taken to make the

\footnotetext{
${ }^{1}$ von Huene, R., Aubouin, J., et al., Init. Repts. DSDP, 84: Washington (U.S. Govt. Printing Office)

2 Addresses: (Ogawa) Department of Geology, Kyushu University 33, Hakozaki, Fukuoka 812, Japan; (Miyata, present address) Environmental Geology Department, Geological Survey of Japan, Yatabe, Ibaraki 305, Japan.
}

sections both for $\mathrm{X}$-ray radiography and microscopic observation. The usual sample size was about $2.5 \times 3.0 \times 1.5 \mathrm{~cm}$. Samples were packed in polyethylene tubes, which kept them moist.

The samples were first removed from tubing and weighed wet using a Metler Analytical Balance (Model H31 AR); the wet volume was then measured by Beckman Air Comparison Pycnometer (Model 930). The samples were then put into an oven drier for $24 \mathrm{hr}$. at $105^{\circ} \mathrm{C}$ to expel the void water, and after that the dry weight was measured. The results of wet bulk density, dry density, and porosity are listed in Table 1 . For comparison, Table 1 also represents data from mudstones in which vein structures did not occur.

Next the dried samples were impregnated with a toluene-epoxy resin mixture in a vacuum-desiccator for $3 \mathrm{hr}$. and the cement was allowed to harden for 3 days. One face of each sample was carefully polished using sandpaper and was attached with epoxy resin to a polyethylene film $1.0 \mathrm{~mm}$ thick. The attached samples were cut by a diamond saw and polished to about 2-mm-thick slabs. X-ray radiographs were taken using a Softex Instrument (Type CM) at $30 \mathrm{kV}, 3 \mathrm{~mA}$, and 60 -s exposure. These pictures are shown in Plate 1. Some thin sections photographed under reflected light are shown in Plate 2 for comparison. The rest of the samples were repolished, attached to a glass slide with epoxy resin and heated at $80^{\circ} \mathrm{C}$ for 1 day. Samples were cut by a diamond and polished with sandpaper to make thin sections as thin as $0.03 \mathrm{~mm}$. These thin sections were studied using a polarizing microscope, and photomicrographs were taken.

\section{DEFINITIONS AND GENERAL CHARACTERISTICS OF VEIN STRUCTURES}

Although many new varieties of vein structures have been recognized in this study, their general characteristics and development are similar to those described by Cowan (1982) for Leg 67 (in the same area as that of Leg 84 off Guatemala) and by Ogawa (1980) in the onland Miocene Miura Group in central Japan. The same structures are also described as veins from the landward slope areas of the Japan Trench, Leg 57 by Arthur et al., (1980) and as spaced foliations from the Middle America Trench off Mexico, Leg 66 by Lundberg and Moore (1981). These veins are typically characterized by "subparallel planar structural discontinuities, generally less than $2 \mathrm{~mm}$ thick, which appear on the face of cut cores as dark linear, curved or braided traces" (see Cowan, 


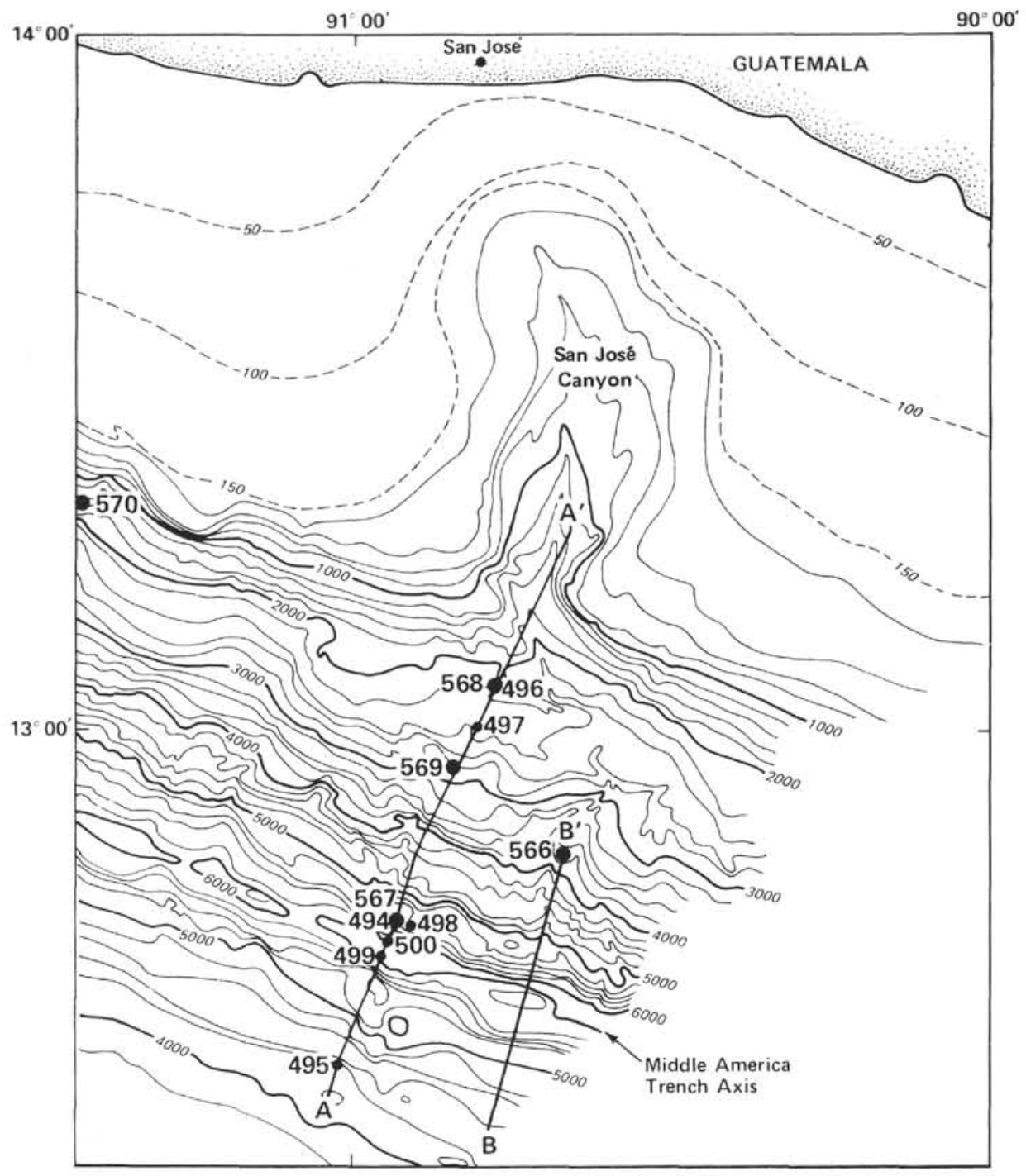

Figure 1. Location map of Sites 568 and 569.

1982). They occur in fine terrigenous, sometimes diatomaceous, mudstone. The thickness of veins ranges from 0.01 to $0.5 \mathrm{~mm}$ and the veins are spaced about 0.5 to $2 \mathrm{~mm}$. The shapes of veins are variable but are often sigmoidal and 1 to $3 \mathrm{~cm}$ long on the cut face. The shapes are classified into several types, as described later, the most typical being braided. The important fish type is shown in Figure 3.

The development of veins is controlled by the lithology. Veins are preferentially developed in fine-grained muddy sedimentary rocks and are apt to vanish in coarser units. Thus veins are concentrated in definite lithology, so that the zone of concentration may sometimes indicate the bedding trace. But there are several exceptions, as shown later. Lithology usually changes perpendicular to the bedding but sometimes changes laterally, depending on the content of calcite or other characteristics such as burrows or trails. Calcareous burrow fills, mottles, or concretions are usually sandy, therefore veins terminate against or go around them (examples are shown in Appendix: Sample 569-24-4, 58-67 cm; 568-30-2, 135-138 $\mathrm{cm} ; 568-29-6,41-42 \mathrm{~cm}$ ), although rarely veins cut them (example in Appendix: Sample 569A-1-1, 95-105 cm) (see also Plate 4). Veins usually diminish in the coarsegrained parts, gradually narrowing, braiding, or joining together. These characteristics mean that veins are widest in the central parts, and gradually thin laterally, as they are braided and joined.

Veins have rather little dislocation along their length, which means that the veins are essentially joints; however, displacement on the order of millimeters is sometimes seen. Therefore some veins may be small faults, which clearly cut and dislocate stratigraphic features; on the other hand, small faults are very similar to veins in their internal characteristics. (This can be seen in Figure 6.)

Veins are characterized by their darker color (Plate 2, Fig. 4) and concentration of much finer materials within the vein trace. These are apparent in the X-ray radiographs as black lines (Plate 1, Figs. 1-3, 11, etc.). Microscopic observation also indicates tiny opaque materials in and along the grains of clay in the veins (Fig. 4). 


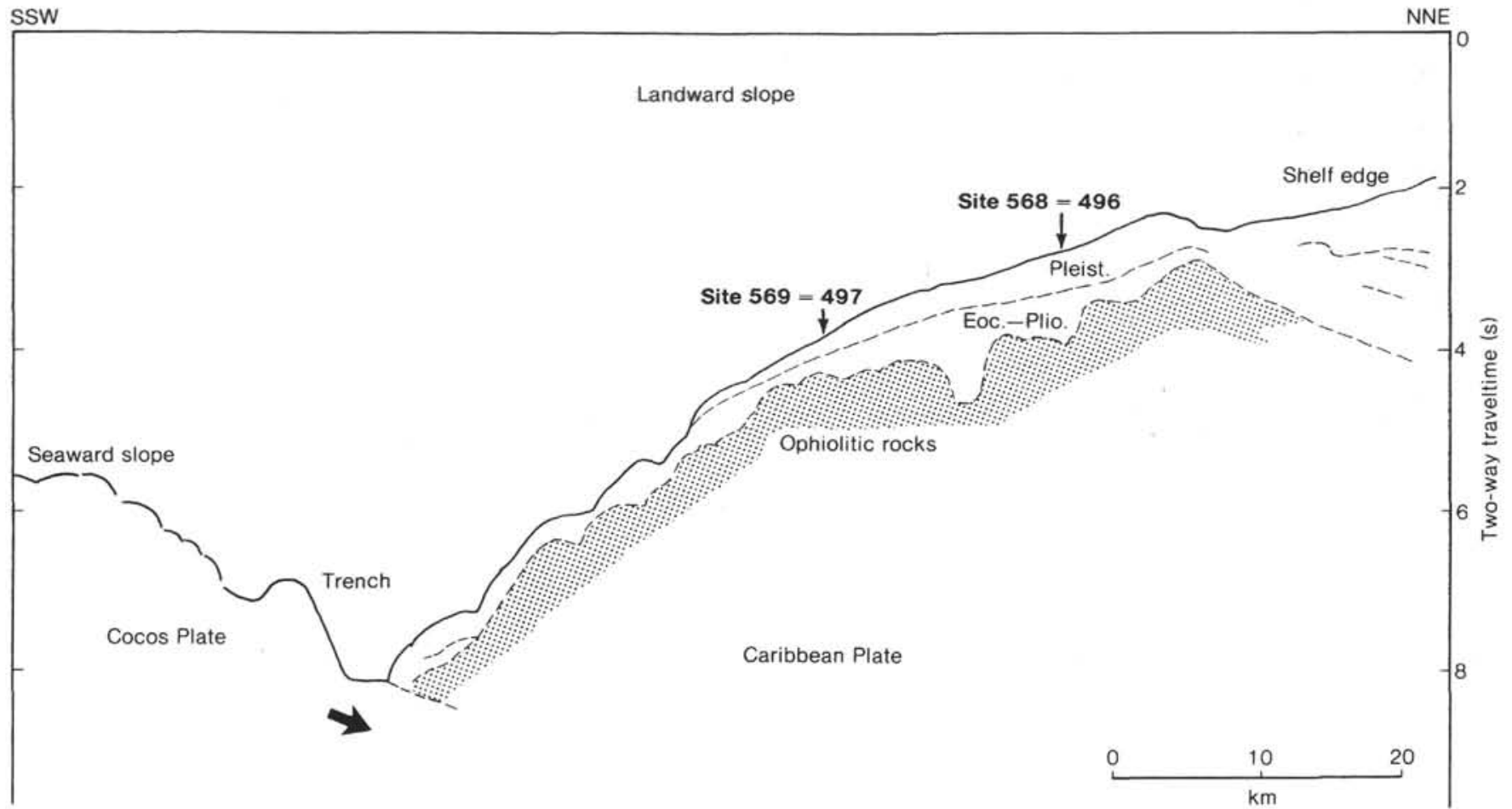

Figure 2. Cross section of the Middle America Trench off Guatemala. Sites 568 and 569 are in the middle slope, where thick Miocene and Pleistocene sediments are deposited on irregular basement topography. Note that the middle slope shows a rather gentle surface.

Table 1 . Wet and dry density and porosity of mudstone.

\begin{tabular}{|c|c|c|c|c|c|}
\hline $\begin{array}{c}\text { Sample } \\
\text { (cm interval) }\end{array}$ & $\begin{array}{l}\text { Sub-bottom } \\
\text { depth } \\
\text { (m) }\end{array}$ & $\begin{array}{c}\text { Wet } \\
\text { density } \\
\left(\mathrm{g} / \mathrm{cm}^{3}\right)\end{array}$ & $\begin{array}{c}\text { Dry } \\
\text { density } \\
\left(\mathrm{g} / \mathrm{cm}^{3}\right)\end{array}$ & $\begin{array}{l}\text { Porosity } \\
\text { (vol. \%) }\end{array}$ & Age \\
\hline 567 A-3-3, $146-148$ & 220 & 1.92 & - & - & \\
\hline $567 \mathrm{~A}-6 \cdot 4,32-34$ & 250 & 1.77 & 1.19 & 58.1 & \\
\hline $567 \mathrm{~A}-8 \cdot 4,43-45$ & 270 & 1.84 & - & - & early \\
\hline $567 \mathrm{~A}-8-4,46-48$ & 270 & 1.90 & - & - & Miocene \\
\hline $567 \mathrm{~A}-13-2,46-47$ & 310 & 3.22 & - & - & \\
\hline $567 \mathrm{~A}-14-1,109-111$ & 320 & 2.28 & 2.00 & 27.8 & \\
\hline $568-23-3,76-80$ & 210 & 2.27 & 2.08 & 18.3 & middle Miocene \\
\hline $568-40-3,20-23$ & 380 & 1.86 & 1.32 & 53.6 & early Miocene \\
\hline $569-13 \cdot 1,0-3$ & 110 & 1.72 & 1.06 & 65.2 & \\
\hline $569-14-1,87-89$ & 120 & 1.80 & 1.18 & 61.9 & \\
\hline $569-15-1,2-5$ & 130 & 1.76 & 1.59 & 18.4 & \\
\hline $569-15-1,34-36$ & 130 & 2.03 & 1.82 & 21.5 & \\
\hline $569-17-3,122-124$ & 150 & 1.74 & 1.13 & 60.8 & early \\
\hline $569-18-1,48-50$ & 150 & 1.82 & 1.55 & 26.3 & Miocene \\
\hline $569-20-1,43-44$ & 173 & 1.91 & 1.71 & 19.0 & \\
\hline $569-21 \cdot 1,10-12$ & 186 & 1.71 & 1.14 & 56.5 & \\
\hline $569-23-4,12-14$ & 210 & 1.93 & 1.48 & 47.7 & \\
\hline $569-26-1,82-84$ & 235 & 1.73 & 1.17 & 55.5 & \\
\hline $569-27-3,50-52$ & 244 & 1.81 & 1.31 & 50.1 & \\
\hline $569-27-3,50-52$ & 244 & 1.85 & 1.34 & 50.1 & \\
\hline $569 \mathrm{~A}-1-3,110-112$ & 250 & 1.86 & 1.39 & 50.9 & late \\
\hline $569 \mathrm{~A}-1-3,130-132$ & 250 & 1.90 & 1.37 & 52.6 & Oligocene \\
\hline $569 \mathrm{~A}-2, \mathrm{CC}(13-15)$ & 260 & 1.87 & 1.30 & 56.9 & \\
\hline $569 \mathrm{~A}-7, \mathrm{CC}$ & 310 & 1.89 & 1.40 & 48.7 & \\
\hline $570-18-2,93-98$ & 170 & 1.77 & 1.39 & 37.5 & late Pliocene \\
\hline $570-37-2,126-128$ & 350 & 2.68 & 2.50 & 16.6 & early Eocene \\
\hline
\end{tabular}

Note: - indicates no data

The color of the vein may be lighter than the surrounding rock, especially when samples are dried or made into thin sections (Fig. 5) (see also, Cowan, 1982). In this case recrystallized clay minerals are included in the veins. In comparing reflected light photographs and X-radiographs, we note that opaque materials are sometimes concentrated along veins, and in some places recrystallized clay minerals occur, as documented by Arthur et al. (1980) and by Lundberg and Moore (1981).

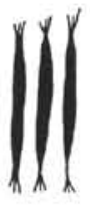

A

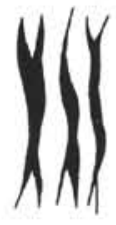

B

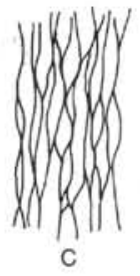

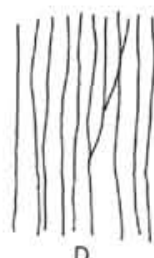

D

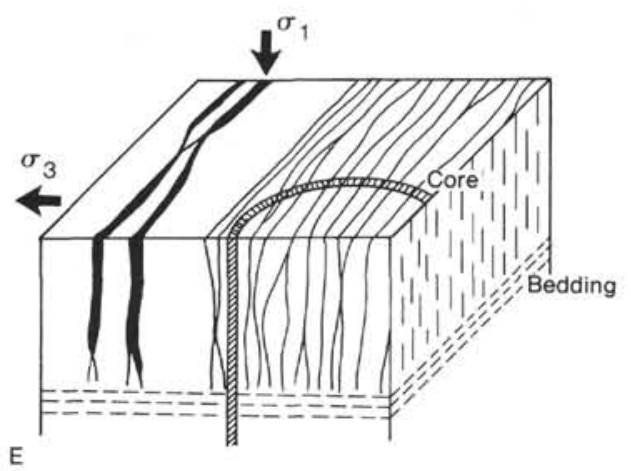

Figure 3. A-D. Types of veins (A. fish type, B. braided type, C. anastomosing type, and D. parallel type). E. Representative cut core.

The major clay mineral both in veins and outside in bulk sample is smectite (d-001 spacing 14.4 $\AA$ ), with minor amounts of illite and kaolinite, similar to the results of Leg 67 (Cowan, 1982). These clay minerals are mostly detrital in origin, but some are altered and slightly recrystallized, because diatom skeletons, which are essentially amorphous or weakly recrystallized silica minerals, are altered to clay minerals in thin sections. 


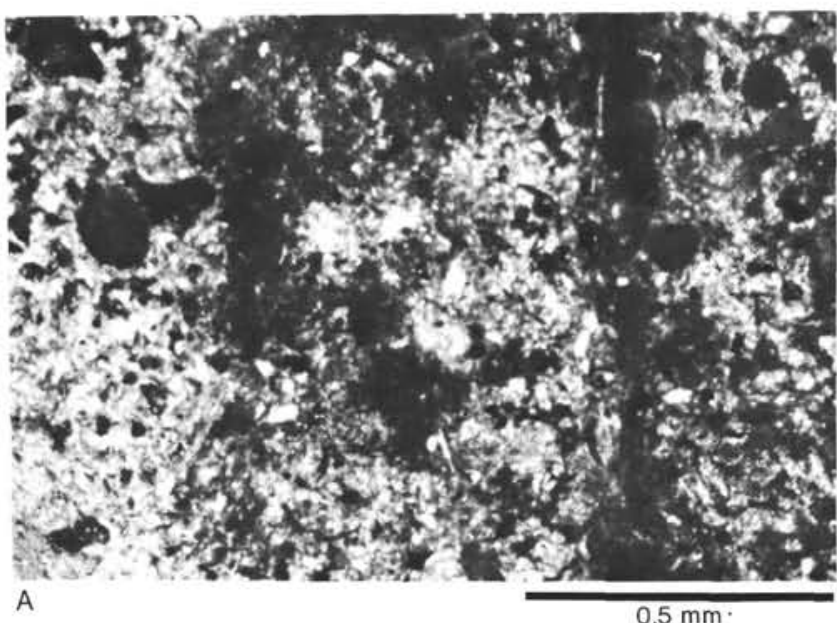

A

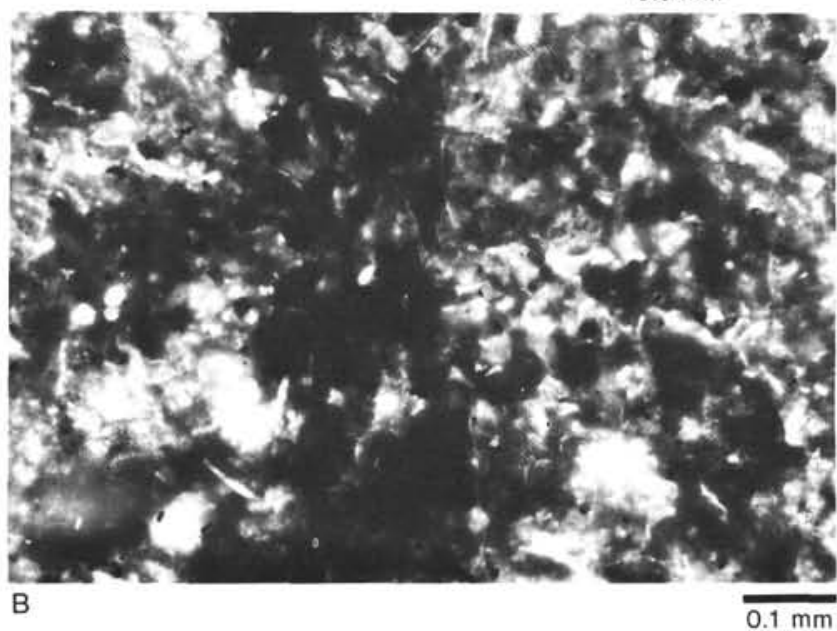

Figure 4. A and B. Photomicrographs within vein, concentrating fine materials. Note that the fibrous materials (diatom spines) are at random on the outside of vein, but lie parallel inside. Sample 569$17-3,122-126 \mathrm{~cm}$ (plain light).

As already mentioned, veins are characterized by finer internal materials, and in addition are characterized by the presence of long laths, paralleling the veins. These features can be observed in most sections (Figs. 4, 5 and 6 ). The long laths are usually diatom spines, but rarely plagioclase. They float in a clay matrix. The clay itself is arranged parallel to the veins, and where it is considerably recrystallized, preferred orientation paralleling the veins can be recognized by the characteristic parallel extinction under the microscope, as shown in Figure 5.

The walls of veins are usually straight, bounded sharply by fine clay grains. There is sometimes a narrow zone separating the veins from surrounding lithologies, and the zone is more characteristic of the small faults (Fig. 6). Vein walls rarely cut the boundaries of microfossils, for example, foraminifer, diatom, or radiolarian. When samples are scraped off along the veins, tiny striations are seen parallel to the direction of the vein, as shown by Cowan (1982), G. Moore (1980), and Arthur et al. (1980). This phenomenon may be caused by displacement along the vein wall.
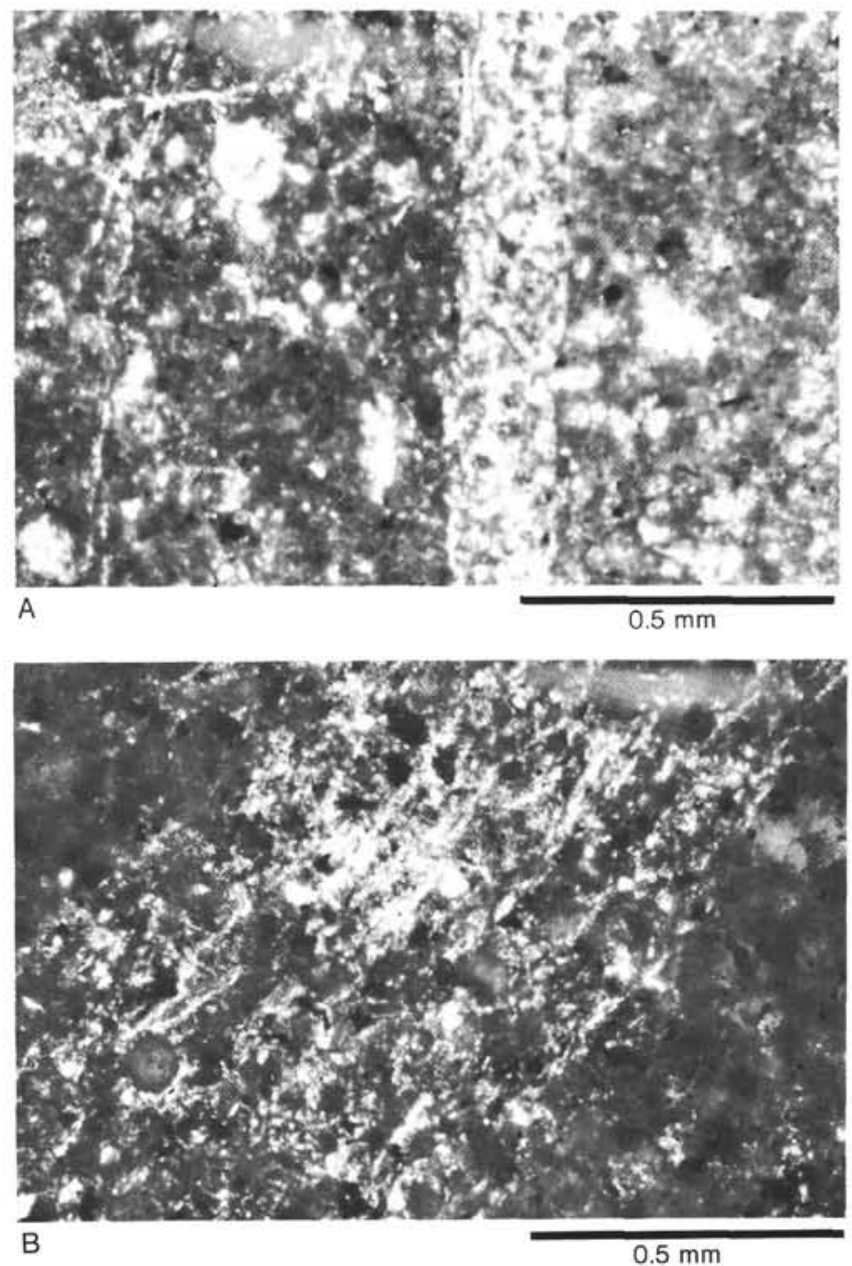

Figure 5. Photomicrographs of light-colored vein concentrating clay minerals. Note that the clay minerals are aligned parallel to the vein direction in the lower vein. A. Sample 569A-1-3, 130-132 cm (plain light). B. Sample 569-17-3, 122-124 cm (crossed nicols).

\section{DEVELOPMENT AND ORIGIN OF THE VEIN STRUCTURE}

\section{Classification of Vein Shape}

As the veins are observed on a vertically cut plane, three dimensional features are not always obtained. When the bedding is horizontal, the plane is usually perpendicular to subperpendicular to the bedding plane (Fig. 3 ). Four forms of vein can be recognized according to the apparent traces in the cut plane: (1) fish type, (2) braided type, (3) anastomosing type, and (4) parallel type (Fig. 3). Each type may grade into another, and they are originally related to each other. Considering the three-dimensional features, the fish type is the basic one. It sometimes branches vertically to make the braided type; when more branches occur, the anastomosing type is formed. Sometimes, a further variety of the anastomosing type is seen-the conjugate type (Fig. 7). When one cutting plane is perpendicular to the vane plane and parallel to the zone of the vein, the assemblage of the vein observed is of the parallel type, as shown by Cowan (1982, plates 1-4). In general all these 

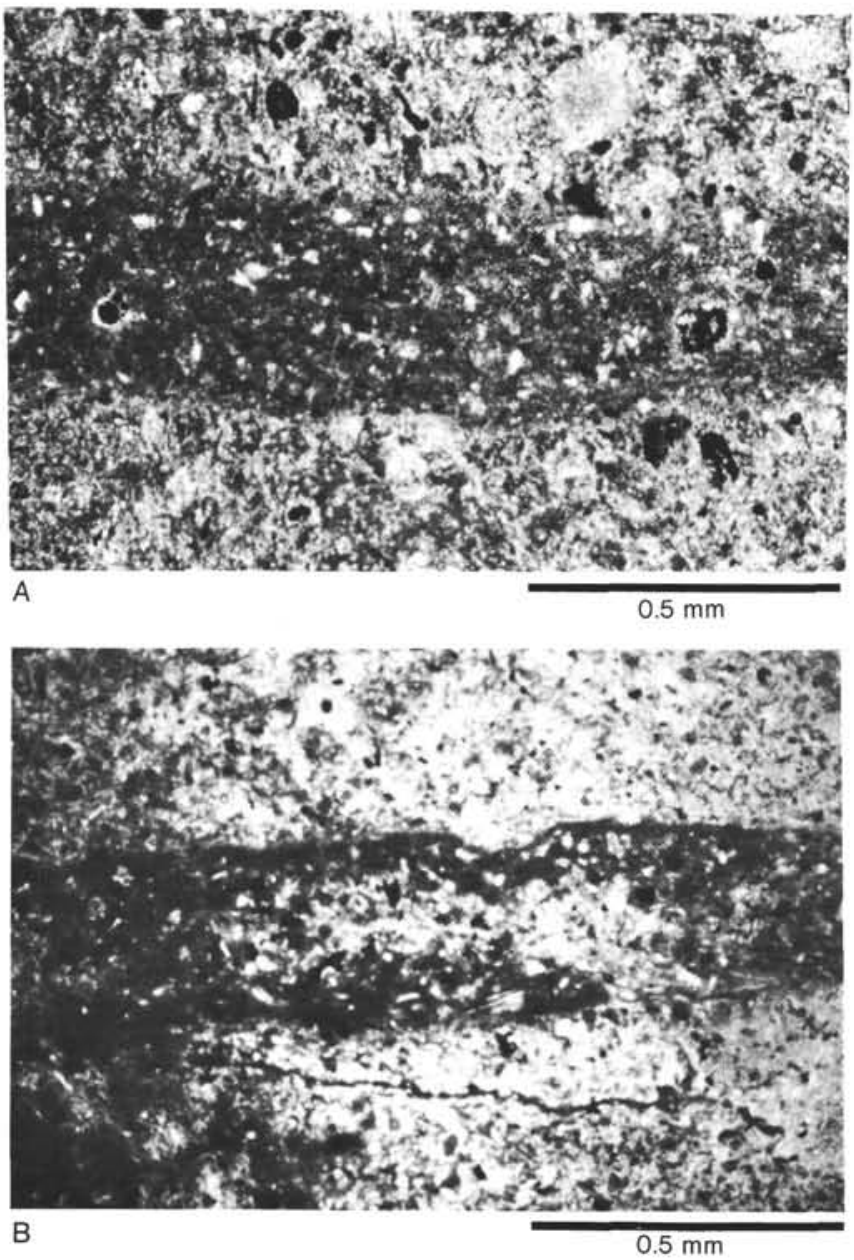

Figure 6. Photomicrographs comparing A. vein-Sample 569-27-3, $50-52 \mathrm{~cm}$, and B. fault-Sample $569-18-1,48-50 \mathrm{~cm}$. The two are very similar, but note that the wall boundaries are different-that in the vein is not so sharp as in the fault. Fine materials are much more concentrated along the walls in the fault.

vein types are usually sigmoidally curved, and the term "sigmoidal vein" is generally used.

Overall orientation of veins is generally vertical in the shallow depth where bedding is only gently inclined, but very variable in the deeper part where bedding is more steeply inclined (see Appendix).

\section{Relation Between the Shape and Bedding Plane}

The four types of veins are differently developed, depending upon the angle between vein and bedding. Generally, veins are parallel to the bedding are of the parallel type. The anastomosing type is common in veins developed moderately obliquely to the bedding plane. On the other hand, fish and braided types are common in veins almost perpendicular or at high angles to the bedding plane. These variations are shown in the Appendix and Plates 1 to 6.

The variation of shapes relative to the bedding plane may be related to the origin of the vein itself. Some veins parallel to the bedding plane apparently occur first by bedding slip: these are simple fractures now healed. The first-generation fractures are then cut by those at high or moderate angles to the bedding plane (e.g., Appendix: Sample 568-30-2, 115-117 cm), usually of braided or anastomosing type, probably caused by some shearing stress, which makes the edge of the veins develop obliquely to main part, as discussed later.

\section{Rotation and Dragging of Veins}

Most of the veins seem to have been rotated or dragged with respect to the zone of the veins to make the veins sigmoidal in shape. When the rotation is much more in the center of the vein than in the tail, it is not caused by drag but by rotation. In some cases only the main part of the vein rotates and the tail remains in the original direction. If we assume the slip occurs along the zone of the vein, the rotation is further classified into (1) updip rotation and (2) downdip rotation (Fig. 8A and B). When the tail is rotated in the same direction as, but to a greater extent than, the central part, the rotation is caused by drag, rather than by rotation. This movement is classified into (3) updip drag and (4) downdip drag (Fig. 8C and D).

In general, tension gash or en echelon veins in hard rocks are usually filled with quartz or calcite, and are almost always type 2 forms (Ramsay and Graham, 1970). This is because such veins originated from extensional fractures aligned in zones of high shear stress, mostly at about $45^{\circ}$ to the maximum compressive stress axis. The right fractures were then rotated by means of the shearing to form downdip rotation. In our samples all these four types are observed, but downdip rotation (2) and downdip drag (4) are predominant (see Appendix). The downdip shearing may be responsible for the bedding tilting during the development of the vein, as discussed by Cowan (1982).

\section{Distribution of Vein Structures}

Some of the Leg 84 Sites are in a similar position to those of Leg 67, for example, Site 568 is very near Site 496, and Site 569 is close to Site 497 . Vein structures are only found in these four sites.

Site 568 is situated midslope $47 \mathrm{~km}$ on the landward side from the Trench axis at $2010 \mathrm{~m}$ depth. Site 569 is also in the middle slope, but a little seaward of Site 568 , $32 \mathrm{~km}$ landward from the Trench axis and at $2770 \mathrm{~m}$ depth. At present these two sites are in bathyal environment, and receive muddy, slightly diatomaceous biogenic, terrigenous sediments. The paleodepth history deduced from benthic foraminifers by McDougall (this volume) indicates that both sites were at bathyal to abyssal depths from the early Miocene until the Pleistocene; therefore, from Miocene to Recent this Trench landward slope underwent gradual uplift.

At Site 496, Cowan (1982) reports the first appearance of veins in Core 24 (about $296.5 \mathrm{~m}$ sub-bottom). These become abundant in Core 30 and below. At Site 568 , the first appearance of the veins is in Core 27 (about $250 \mathrm{~m}$ sub-bottom; middle Miocene), and they become abundant just below that depth. In Core 30 and below, two sets of interesting veins are observed together with a variously inclined bedding plane (Appendix). In Core 42 , zones of veins developed nearly vertically, which 

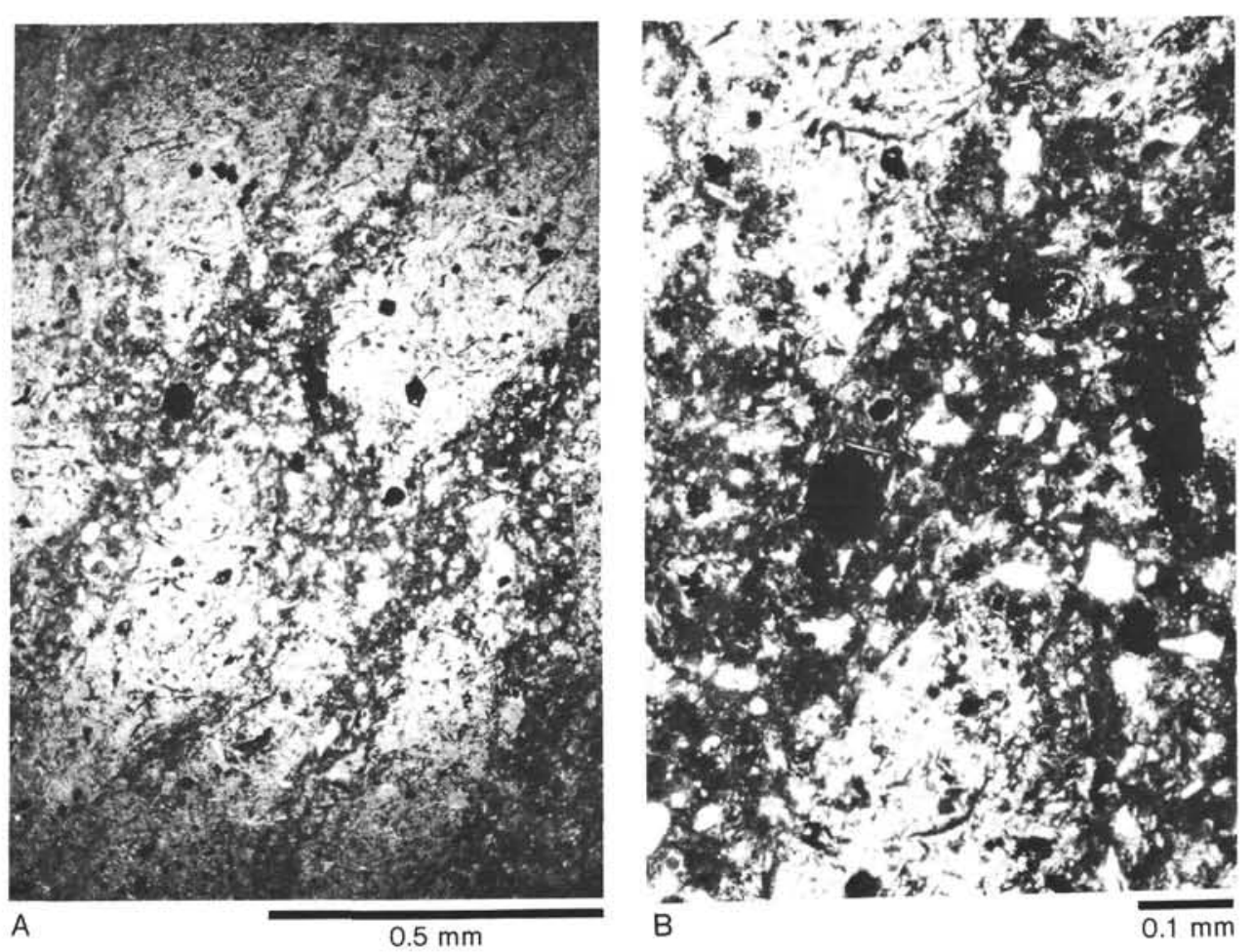

Figure 7. A and B. Photomicrographs of conjugate type of veins. Note that the veins are straight and braided sporadically. Sample 569-15-1, 2-5 cm.
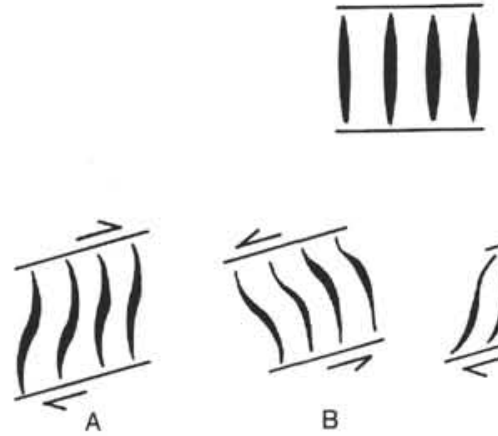

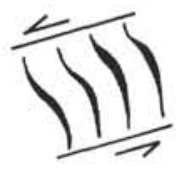

B

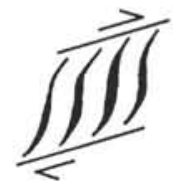

C

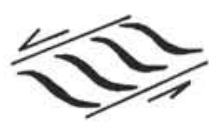

D
Figure 8. Types of rotation and drag of veins by slip. A. Updip center rotation. B. Downdip center rotation. C. Updip drag. D. Downdip drag.

suggests that the bedding plane dips almost vertically, because the zone of veins is usually parallel to the bedding trace, as mentioned before.

At Site 497, Cowan (1982) reports the first appearance of veins in Core 17 (about $152 \mathrm{~m}$ sub-bottom), and they become abundant in Core 25 and below (about $225.5 \mathrm{~m}$ sub-bottom). At Site 569, we observed the first appearance of veins in Core 14 (about $120 \mathrm{~m}$ sub-bottom), and they become abundant in Core 15 and below. At Hole 569A, the development of vein structure is not seen below Core 2 (about $269 \mathrm{~m}$ sub-bottom, late Oligocene).
At both Sites 568 and 569 , veins are mostly developed only Miocene sections, are rare in the Oligocene and Eocene sections, and do not occur in the Pliocene and younger sections. Because no sites other than 568 (496) and 569 (497) have any vein structures in upper and lower Trench landward slope areas and in the Trench axial part and Trench seaward slope (Cowan, 1982; see also Legs 67 and 84 Site reports), veins appear to be restricted to Miocene strata in the middle Trench landward slope area.

Veins are commonly seen where rocks are hard enough to form long cores (e.g., the rate of core recovery changes abruptly from 30 to $90 \%$ in Core $569-15$, below which veins abundantly appear); there is a mutual relation between the hardness of the cores and development of veins (Fig. 9). This figure shows that the bedding becomes steeper with depth at Site 568; it is not monotonic at Site 569. In the shallower parts, bedding is almost horizontal, and always more gently inclined than $20^{\circ}$. However, at Site 568, in Cores 20 and below, where veins are well developed, the bedding is inclined at $20^{\circ}$ or more, and becomes very steep in Cores 40 and 41 (see Appendix). In Core 42 abundant veins are developed in a zone along the bedding plane (Appendix; Plate 6). Minor faults parallel to the bedding cut the veins. These are the later fractures probably caused by the downdip slip. At Site 569, apparent bedding becomes steeper in Core 13 and below, where veins are complexly developed (Ap- 


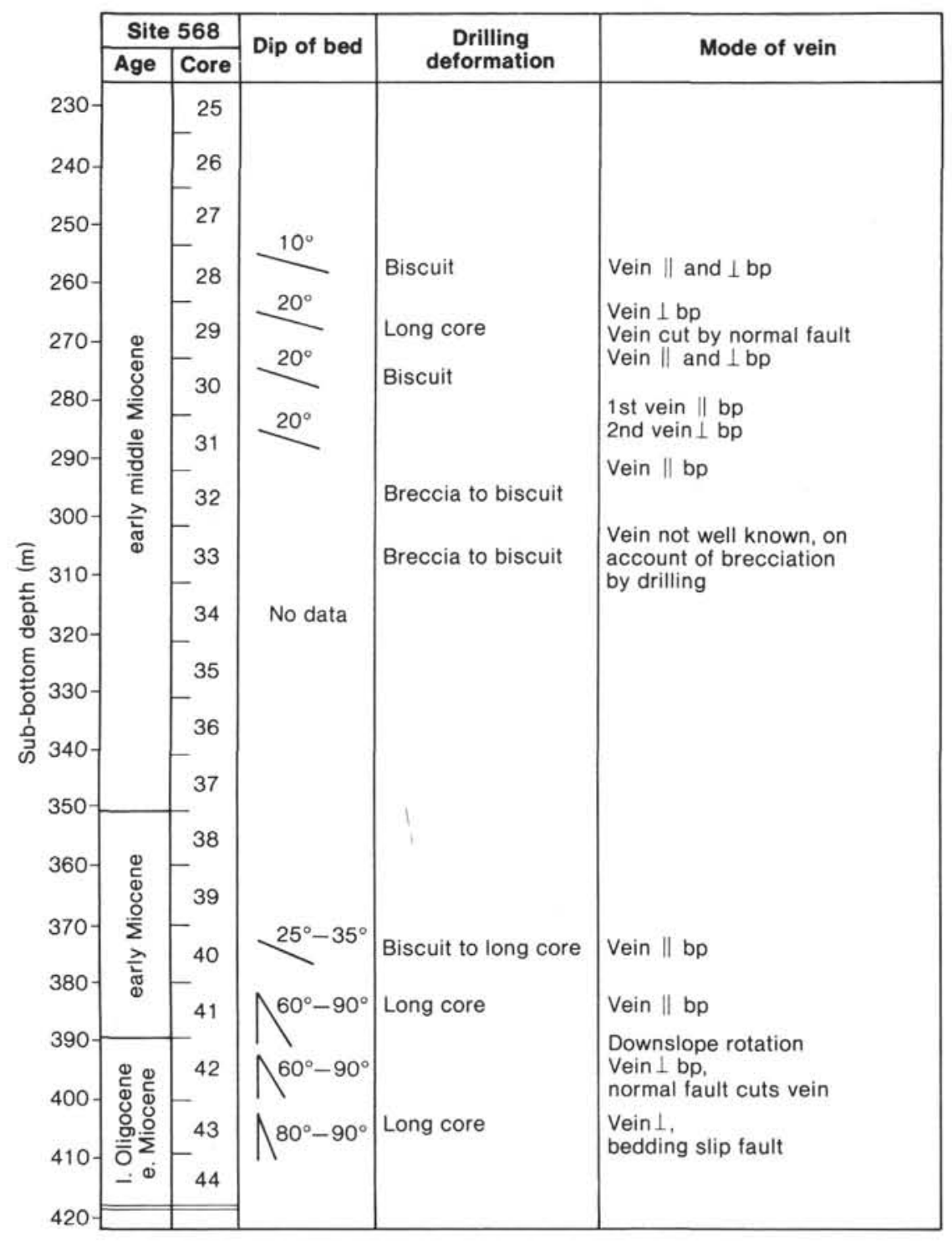

\begin{tabular}{|l|l|l|l|l|}
\hline \multicolumn{1}{|c|}{ Site 569 } & Dip of bed & \multicolumn{1}{|c|}{$\begin{array}{c}\text { Drilling } \\
\text { deformation }\end{array}$} & \multicolumn{1}{|c|}{ Mode of vein } \\
\hline Age & Core & Dip \\
\hline
\end{tabular}

Figure 9. General summary of bedding inclination, drilling deformation and mode of development of vein at Sites 568 and 569 (Holes 569 and 569A). Parallel and reversed T marks in the right columns mean parallel or subparallel and vertical or at high angles, respectively; bp is trace of bedding plane. 
pendix). The bedding then reverts to nearly horizontal again in Core 26 and below.

The dip directions of beds are unfortunately not known, whether seaward, landward, or any other direction, as noted by Niitsuma (1981) for Leg 66. However, there are very few folds observed in these sections, and no reversed bedding strata repetition or large normal or reverse faults have been documented, therefore the bedding change may be associated with simple warping or with drape folding.

\section{Origin of Vein Structures}

Veins are rarely parallel, closely spaced, planar structural discontinuities occurring in a roughly constant direction within one sample. Veins contain finer particles than the surrounding rock types. Vein walls are straight and do not show any loss of cohesion. Small laths of plagioclase or diatom spines in veins are arranged parallel to the vein direction. These characteristics indicate that the veins first originated as fracture cleavages or as very closely spaced joints (Ogawa, 1980; Cowan, 1982). At that time the sediments were fairly consolidated and had considerable strength. But even at this stage, they contained considerable amounts of water. This is seen in the porosity values of the rocks that contain vein structures (Table 1). Porosity even now is as high as about 30 to $50 \%$.

Vein structures are sometimes considered to be the products of dewatering processes (Arthur et al., 1980; Ogawa, 1980; Cowan, 1982). However, in a comparison of on-land examples and those produced in the laboratory, we recognize a variety of similar structures. The same vein structures are observed in the Miura and Boso Peninsulas, Japan (Fig. 10A) (Ogawa, 1980). Veins are well controlled by lithology and normal fault tectonics, having developed slightly after sedimentation, but during the development of the Miocene sedimentary basin. Sometimes we observe vertical light-colored pipes in a thick sandstone layer (Fig. 10B); this is not a vein as defined in this chapter, but a water-escape structure formed in sandy sediment as the dewatering product of an early stage of consolidation. In laboratory experiments we obtained vein structures very similar to those mentioned in this chapter (Fig 10C), but this kind of vein is very soft, produced in the earliest stage of sedimentation almost under a liquid condition. This is not related to the tectonically or sedimentarily induced stress-strain relation, but truly caused by the dewatering instability of the soft sediments. The evidence is not adequate to identify veins described in this chapter as dewatering structures, although veins are probably formed in the later stage of dewatering. Rather, the vein is considered to be a tectonically induced fracture cleavage or joint. The process of vein formation is explained as follows.

When the stress exceeds the brittle strength, the rocks expand forming fractures; consequently the fracture surface undergoes a pressure drop, and water seeps into the low pressure zone. The water carries finer sedimentary particles such as clay or organic fragments to form the darker vein filling (Fig. 11). The water seeps into the fracture from the beginning of the fracture toward the
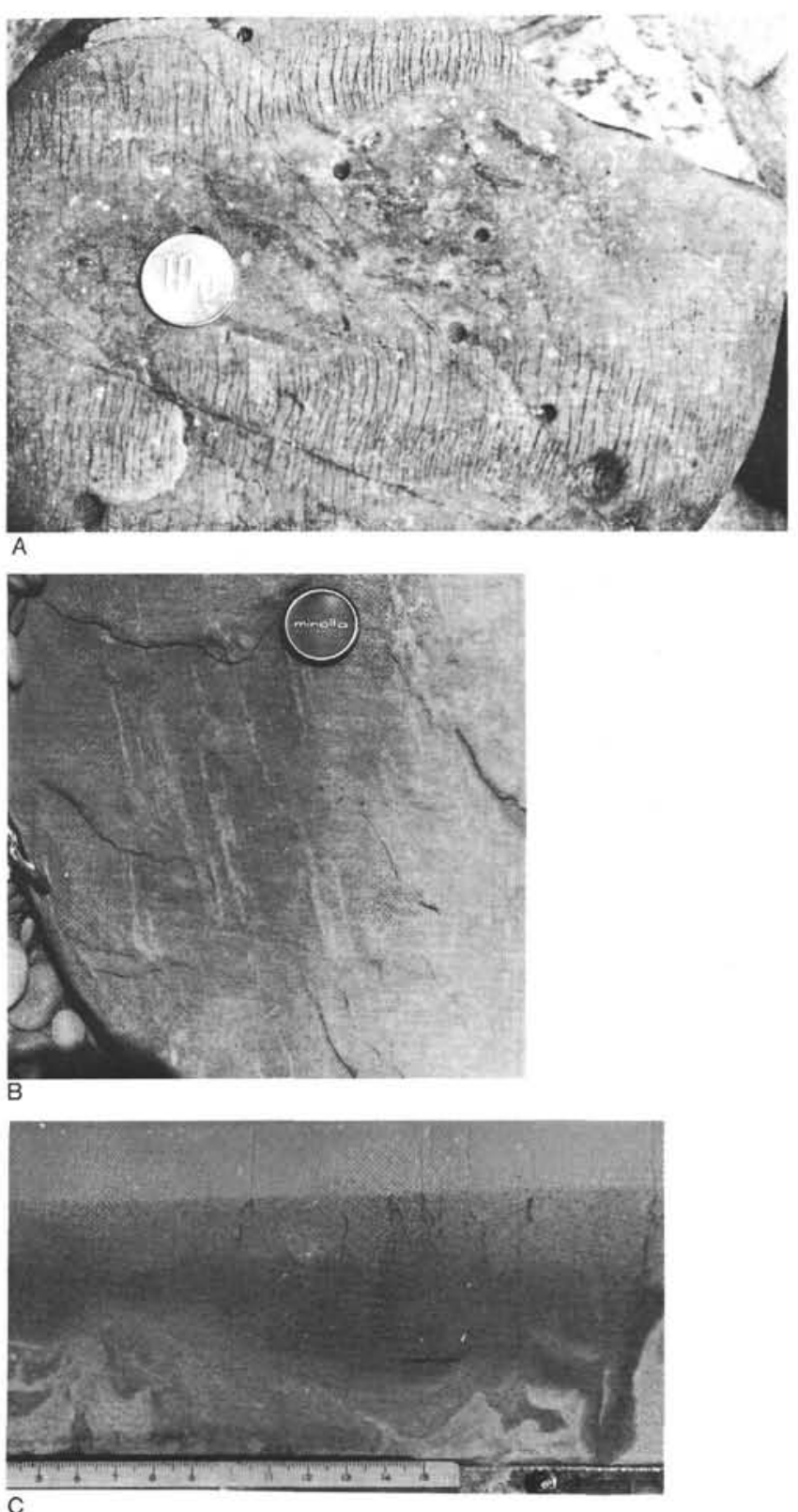

Figure 10. Examples of the same and similar but different kinds of structures. A. Structures in the Miocene Miura. Group, Kuruwa, Miura Peninsula, Japan. B. Sand pipe as dewatering phenomena in sandstone of Oligocene Nichinan Group, Toi Peninsula, Japan. C. Experimentally induced vein structure in soft sand and mud on extremely liquidized sand and mud.

edge; the former becomes the central, main, and widest part, and while the latter becomes braided or branched to form the tail of the vein.

The void ratio or the water content is higher in clayrich finer sediments than in coarser ones. Finer marine sediments include more clayey materials and silica minerals; some from the fragments of biogenic material are apt to be cemented, making the sediment more cohesive than in the coarser units. The coarser units are still relatively soft and have some fluid properties and low cohesion: under even a small stress difference they cannot maintain their texture. When the differential stress oc- 


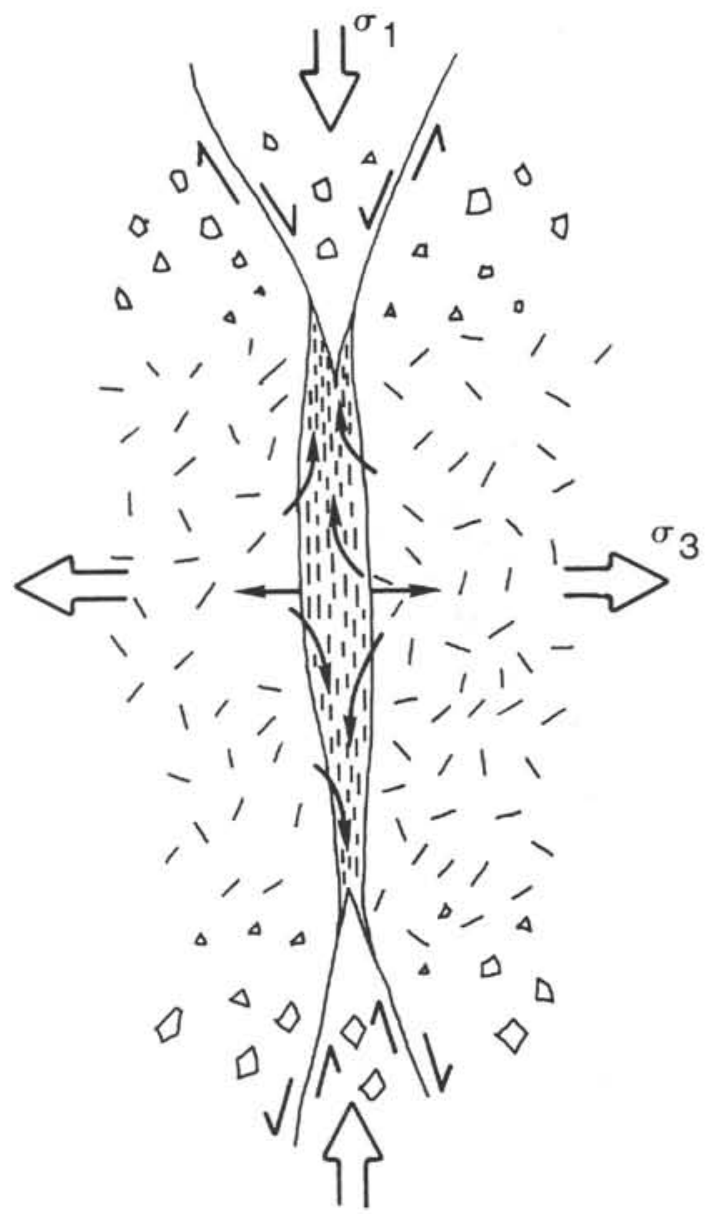

Figure 11. Model of the first stage of development of a vein showing principal stress directions $\sigma_{1}$ and $\sigma_{3}$.

curs over the whole rock, the coarse part may flow and show no remaining significant fracture. Fractures in the finer sediments stop at the coarser part, sometimes braided and thinned out there. These observations are similar to those of Ogawa (1980) and Cowan (1982).

Sometimes a certain amount of shear stress occurs along the fracture. Even a small amount of shearing causes a small displacement along the wall of the fracture. On failure, expansion causes a pressure drop which allows fluid injection.

If the area still maintains the stress difference, other modifications may occur. One is rotation or drag caused by downdip or updip shearing. Another is noncoaxial development of veins.

If a different stress-strain condition occurs, other styles of deformation may occur, that is, faulting or other fractures such as microshear surfaces or shear conjugate planes (Arthur et al., 1980; von Huene et al., 1981; Lundberg and Moore 1981). Usually sedimentary rocks gradually compact and have much greater strength to maintain much greater stress differences: the second fracture modification may contain increased strain, such that shear planes develop rather than joints. Vein formation must occur before such a state.

When the beds are continuously tilting by means of large-scale tectonic movement or a certain kind of slump- ing or sliding, other stress conditions should occur. In this case, either a second set of veins would form in a different direction or rotation or drag would occur along veins or zones of veins. Several stages of vein development are thus explained for the many examples shown in the Appendix.

As explained before, rotation and dragging of the veins are deep in almost all examples. Most vein occurrences show downdip rotation, which means the vein underwent downdip rotation during its evolution. This indicates that the bedding slip usually occurred downslope. Such shearing may have occurred during the gradual tilting of beds (Cowan, 1982). The branching and anastomosing of veins that bear some of the shear stress may also have occurred during the process.

\section{TECTONIC SIGNIFICANCE OF THE DEVELOPMENT OF THE VEIN STRUCTURES}

It should be noted that the veins are nearly confined to Miocene sedimentary rocks, not being present in younger rocks or strata, and being scarce in older rocks. Veins are also restricted to the middle Trench landward slope area and are not found in upper and lower Trench slope areas. Similar conditions prevail in the same Trench slope area off Mexico (Lundberg and Moore, 1981). These findings indicate that veins are restricted to nearly the same age and tectonic setting as in the Middle America Trench. Vein development may thus require certain tectonic and sedimentary conditions.

From the data of micro- and nannofossils, the sedimentation rate at Site 569 is as follows: Cores $569-10$ to $569-12$ (nearly middle to late early Miocene) $-7 \mathrm{~m} / \mathrm{m}$.y.; Cores $569-13$ to $569-25$ (early Miocene) $-25 \mathrm{~m} / \mathrm{m} . \mathrm{y}$; Cores 569-26 to 569-27 (late Oligocene) $-7 \mathrm{~m} / \mathrm{m}$.y.; Cores 569A-2 to 569A-7 (late Oligocene) - $23 \mathrm{~m} / \mathrm{m}$.y.; Cores $569 \mathrm{~A}-8$ to $569 \mathrm{~A}-9$ (late Eocene) $-7 \mathrm{~m} / \mathrm{m} . \mathrm{y}$.

The sediments from the late Eocene to middle Miocene were developed below or near the CCD (calcite compensation depth) (at about $4000 \mathrm{~m}$ depth) in abyssal areas, and after the sedimentation gap between the middle Miocene and Pliocene, sedimentation resumed in the Pleistocene at a shallower middle-slope depth of approximately $2700 \mathrm{~m}$ (McDougall, this volume). Sedimentation of late Oligocene and early Miocene sediments occurred at the rate of about $25 \mathrm{~m} / \mathrm{m}$.y., but this value must be halved, because the beds are generally tilted at about $60^{\circ}$. However, sedimentation rate at this time was relatively rapid.

Sedimentation rates at Site 568 are less well known, but seem to have been generally faster than those at Site 569, about $66 \mathrm{~m} / \mathrm{m} . \mathrm{y}$. in the middle Miocene and $33 \mathrm{~m} / \mathrm{m} . \mathrm{y}$. in the early Miocene. The dip of the beds is about $30^{\circ}$ so sedimentation rates should be reduced to about 57 and $28 \mathrm{~m} / \mathrm{m}$.y. respectively. The depth of sedimentation was about 500 to $1300 \mathrm{~m}$ (upper middle bathyal) to $2400 \mathrm{~m}$ (abyssal), becoming shallower during the Pleistocene.

The process of sedimentation in the Trench slope area off Guatemala is not fully known, but considering the discussion of sedimentation for Legs 67 and 66 the middle Trench landward slope area was usually the site of 
thick muddy sediment accumulation, with several hiatuses. Timing of major sedimentation varies from site to site: for example, sedimentation occurred chiefly in the early Miocene Site 569 but in the middle Miocene at Site 568.

After the rapid accumulation of fine-grained sediments mostly diatomaceous or terrigenous muds, rapid compaction by self-loading occurred; this compaction consequently resulted in a certain degree of strength. Then during upheaval, tilting, and folding of the sediments, gravitationally or tectonically induced stress caused fracturing which formed the various kinds of vein structures described here. First bedding-parallel veins developed by sliding probably parallel to bedding. This may have been caused by incipient tilting. Second beddingperpendicular veins developed because of vertical compressive stress, which probably also caused normal faulting prevailing in the area. Such stress continued during tilting of the beds, so that veins of various directions intersected the first formed ones. Other tectonic structures such as thrust faults, normal faults, and cleavage are at least not obviously expressed in the area of Leg 84 . This indicates that only weak tectonic stresses have hitherto affected the area. Even though the Trench slope area is situated on the hanging wall side of the subduction of Cocos Plate and might have been subjected to much tectonic stress, no significant evidence of severe deformation was found.

The middle Trench slope has a rather flat surface (Fig. 2). However, the thick sediments present are not always horizontal but may show considerable dips, as discussed in this chapter. The basement is rather irregular, probably having undergone normal faulting. The dip of the beds may be associated with such normal faulting or with slumps and the folding related to either process. Normal faulting generally occurred when the maximum compressive stress was vertical either because of sediment loading or local uplift of the basement. This local uplift may have been caused by a diapiric intrusion of serpentinite (Ogawa et al., this volume). This is why most veins were developed largely perpendicular to the bedding when it was nearly horizontal. During the development of the veins, the bedding may have dipped progressively, such that downslope creep or slump may have occurred. In addition, downdip bedding slip may have occurred through a large-scale folding related to the faulting caused by local uplift of the basement. In this case the stress field parameters were controlled not only by the original vertical maximum axis but also by the additional stresses associated with folding. Thus the local principal stress axis may change. This is the cause of (1) vein rotation or dragging, and (2) the zone of veins showing different directions.

In Section 569-15-1, two sets of very beautiful veins are developed, forming zones of concentration (Plate 6; Appendix). Bedding is inclined at $60^{\circ}$ or more. The first zone of veins is almost perpendicular to the bedding. This zone was probably developed when the bedding was still horizontal. The veins in this zone show downdip rotation. A second zone cuts the earlier one at about $80^{\circ}$ and at that time the zone may have been at a low angle to bedding. This is probably caused by a similar stress condition, but bedding may already have been tilted to a great extent.

From such considerations, we see that veins were apparently developed throughout the tilting of the beds, but possibly to a greater extent during the normal faulting and folding episodes that took place within the middle Trench slope of the Middle America Trench. In the similar area of the Middle America Trench slope off Mexico, Niitsuma (1981) verified paleomagnetically that the strata dip landward because of repeated thrusting in the lower Trench slope, where Schuppen structures form an accretionary prism. On the other hand, he also verified a large-scale seaward drape of folded sediments accompanying normal faulting in the upper-middle Trench slope area, where local vein structures have been reported at Site 484 (Lundberg and Moore, 1981). Off Guatemala, no accretionary prism is known from Leg 67 (von Huene, Aubouin et al., 1981) or from Leg 84 (Aubouin, von Huene, et al., 1982), so there is little evidence for thrust tectonics and only normal faulting is expected.

The Pleistocene sediments show only gentle tilting. The development of veins is not known in the Pleistocene section. Therefore the development of veins probably finished before the sedimentation of the Pleistocene, possibly during the large upheaval between the Miocene and Pliocene, when sediments are lacking throughout the area. Site 567 on the lower slope and Site 570 on the upper slope lack veins apparently because of a sedimentation rate. The formation of gas hydrates may have inhibited vein development at Site 570; intense slumping and sliding may have hindered vein formation at Site 567. In Pleistocene sediments, consolidation was insufficient to strengthen the sediments to allow fracturing.

\section{ACKNOWLEDGMENTS}

We thank all the scientific and technical members of Leg 84 , especially Kevin Reid for taking many beautiful photographs. Thanks are extended to Noriyuki Nasu, Kazuo Kobayashi, and Kametoshi Kanmera for continuous encouragement. Technical help at Imperial College, London, by Grace Lau, Robert Curtis, Richard Giddens, and Martin Gill is gratefully acknowledged. An early draft was reviewed and revised by Andrew Thickpenny, whom we gratefully thank. The manuscript was critically reviewed and revised by J. Casey Moore, Michael A. Arthur, and Miriam Baltuck, to whom we are grateful.

\section{REFERENCES}

Arthur, M. A., Carson, B., and von Huene, R., 1980. Initial tectonic deformation of hemipelagic sediments at its leading edge of the Japan convergent margin. In Scientific Party, Init. Repts. DSDP., 56, 57, Pt. 1: Washington (U.S. Govt. Printing Office), 569-614.

Aubouin, J., von Huene, R., Baltuck, M., Arnott, R., Bourgois, J., Filewicz, M., Helm, R., Kvenvolden, K., Lienert, B., McDonald, T., McDougall, K., Ogawa, Y., Taylor, E., and Winsborough, B., 1982. Leg 84 of the Deep Sea Drilling Project: subduction without accretion: Middle America Trench off Guatemala. Nature, 297: 458-460.

Cowan, D. S., 1982. Origin of "vein structure" in slope sediments on the inner slope of the Middle America Trench off Guatemala. In Aubouin, J., von Huene, R., et al., Init. Repts. DSDP, 67: Washington (U.S. Govt. Printing Office), 645-650.

Lundberg, N., and Moore, J. C., 1981. Structural features of the Middle America Trench slope off southern Mexico, DSDP Leg 66. In Watkins, J. S., Moore, J. C., et al., Init. Repts. DSDP, 66: Washington (U.S. Govt. Printing Office), 793-805. 
Moore, G. W., 1980. Slickensides in deep sea cores near the Japan Trench, Leg 57, Deep Sea Drilling Project. In Scientific Party, Init. Repts. DSDP, 56, 57, Pt. 2: Washington (U.S. Govt. Printing Office), 1107-1112.

Niitsuma, N., 1981. Paleomagnetic results, Middle America Trench off Mexico, Deep Sea Drilling Project Leg 66. In Watkins, J. S., Moore, J. C., et al., Init. Repts. DSDP, 66: Washington (U.S. Govt. Printing Office), 737-770.

Ogawa, Y., 1980. Beard-like veinlet structure as fracture cleavage in the Neogene siltstone in the Miura and Boso Peninsulas, central Japan. Sci. Rept. Dept. Geol. Kyushu Univ., 13:321-327.

Ramsay, J. G., and Graham, R. H., 1970. Strain variation in shear belts. Can. J. Earth Sci., 7:786-813. von Huene, R., Arthur, M. A., and Carson, B., 1981. Ambiguity in interpretation of seismic data from modern convergent margins: an example from the IPOD Japan Trench transect. In McClay, K. R., and Price, N. J., (Eds.), Thrust and Nappe Tectonics, Geol. Soc. London Spec. Publ., 9:393-406.

von Huene, R., Aubouin, J., Azéma, J., Blackinton, G., Carter, J., et al., 1980. Leg 67: Deep Sea Drilling Project Mid-America Trench transect off Guatemala. Geol. Soc. Am. Bull., 91(Pt. 1):421-432.

Date of Initial Receipt: 10 August 1983 Date of Acceptance: 2 March 1984 
$568-23-3,75-77 \mathrm{~cm}$

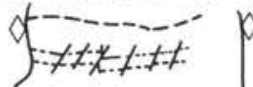

$568-28-2,27-29 \mathrm{~cm}$ (

$568-28-2,41-43 \mathrm{~cm}$ $\{=$

$568-28-2,66-69 \mathrm{~cm}$

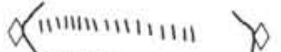

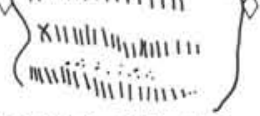
$568-28-2,130-132 \mathrm{~cm}$ $\{\ldots \ldots \equiv\}$ 568-28-4, 46-48 cm

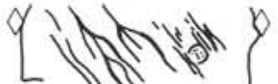
$568-28-4,52-55 \mathrm{~cm}$ $\{\geqslant$ 568-28-3, 130-132 cm $\{$ जill $\leqslant\}$ 568-29-1, 47-51 cm Q ज"III) $\left\{\begin{array}{l}11111111 \\ 1111111111 \\ 2-19\end{array}\right.$
568-30-1, 33-39

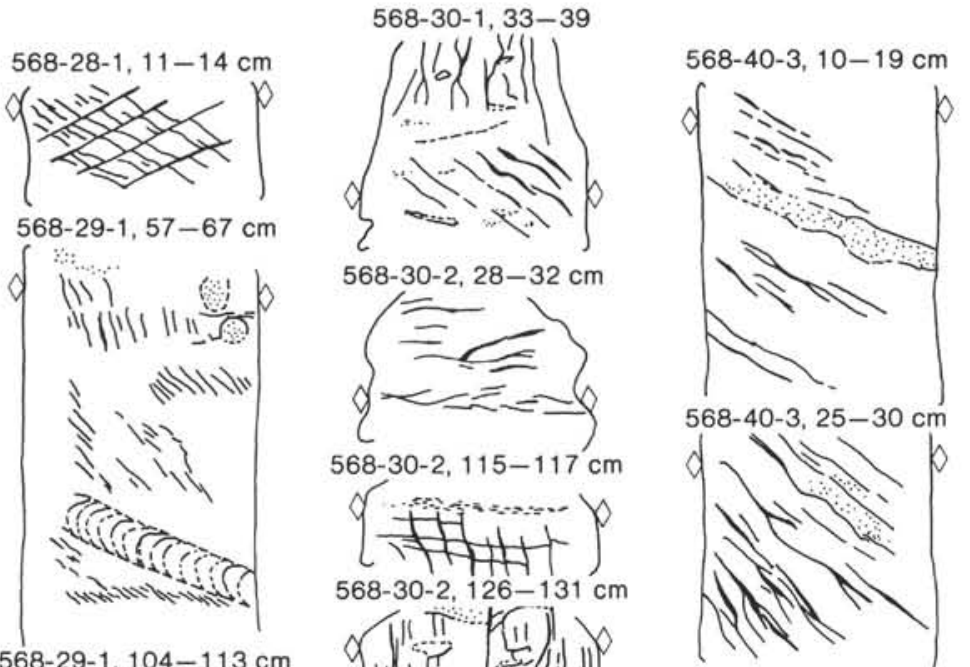
568-29-1, 104-113 cm

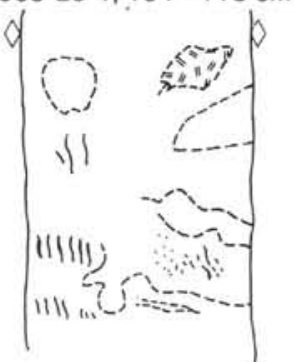

$568-29-5,42-45 \mathrm{~cm}$

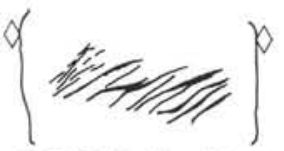

568-29-6, $41-42 \mathrm{~cm}$

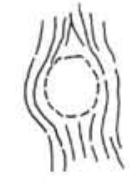

568-41-3, 123-126 cm

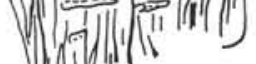

568-30-2, 132-135 cm

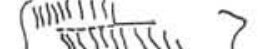

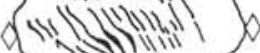
568-32-2, 136-139 cm ( ( 568-30-3, 123-126 cm of

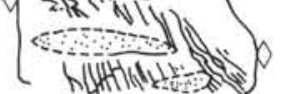
$568-30-4,50-52 \mathrm{~cm}$ of 568-30-4, 104-106 cm

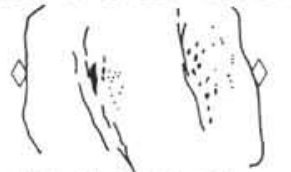

$568-41-4,17-20 \mathrm{~cm}$
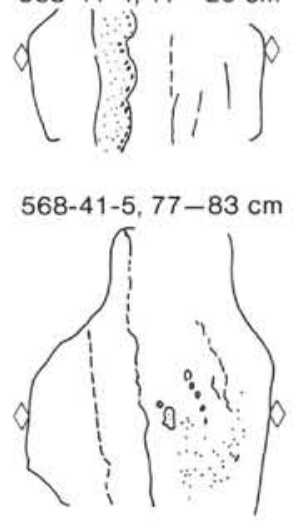
OWMlly? 568-30-4, $120-123 \mathrm{~cm}$

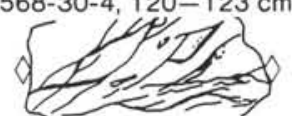

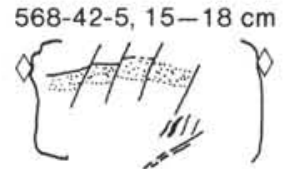

$568-42-5,113-115 \mathrm{~cm}$

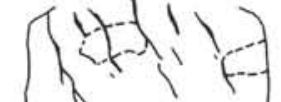

$568-42-6,88-96 \mathrm{~cm}$

of 5

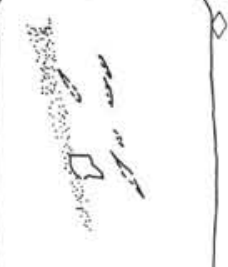

$568-42-7,12-45 \mathrm{~cm}$

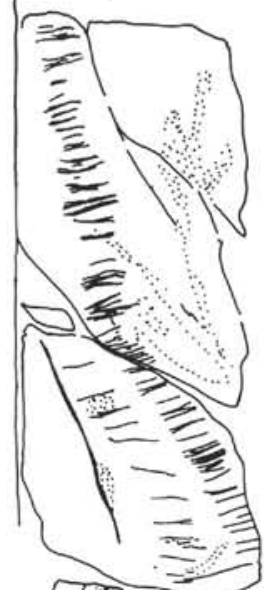

$568-42-6,118-143 \mathrm{~cm}$
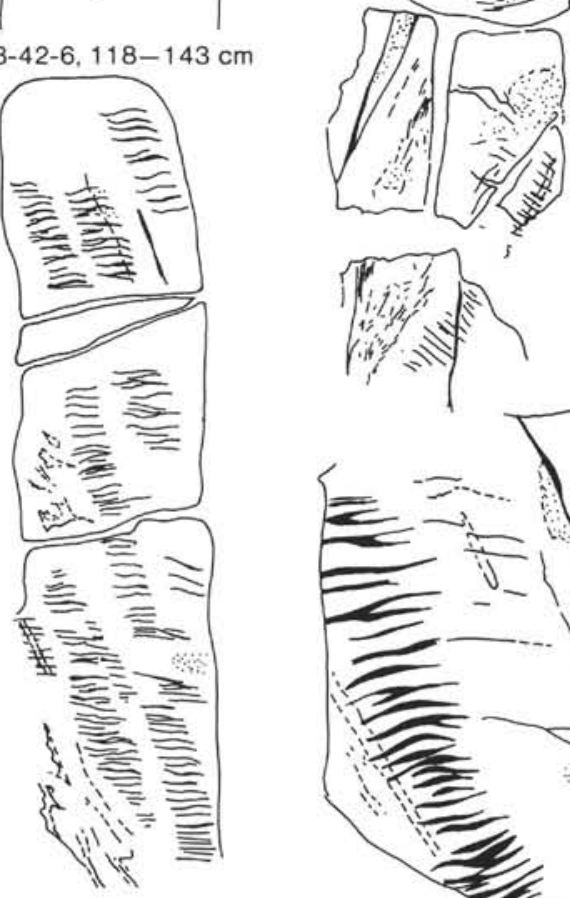

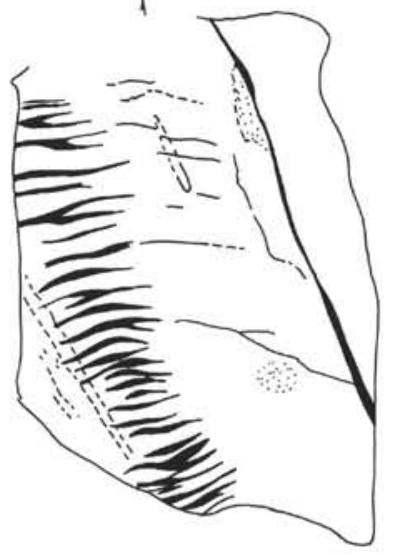




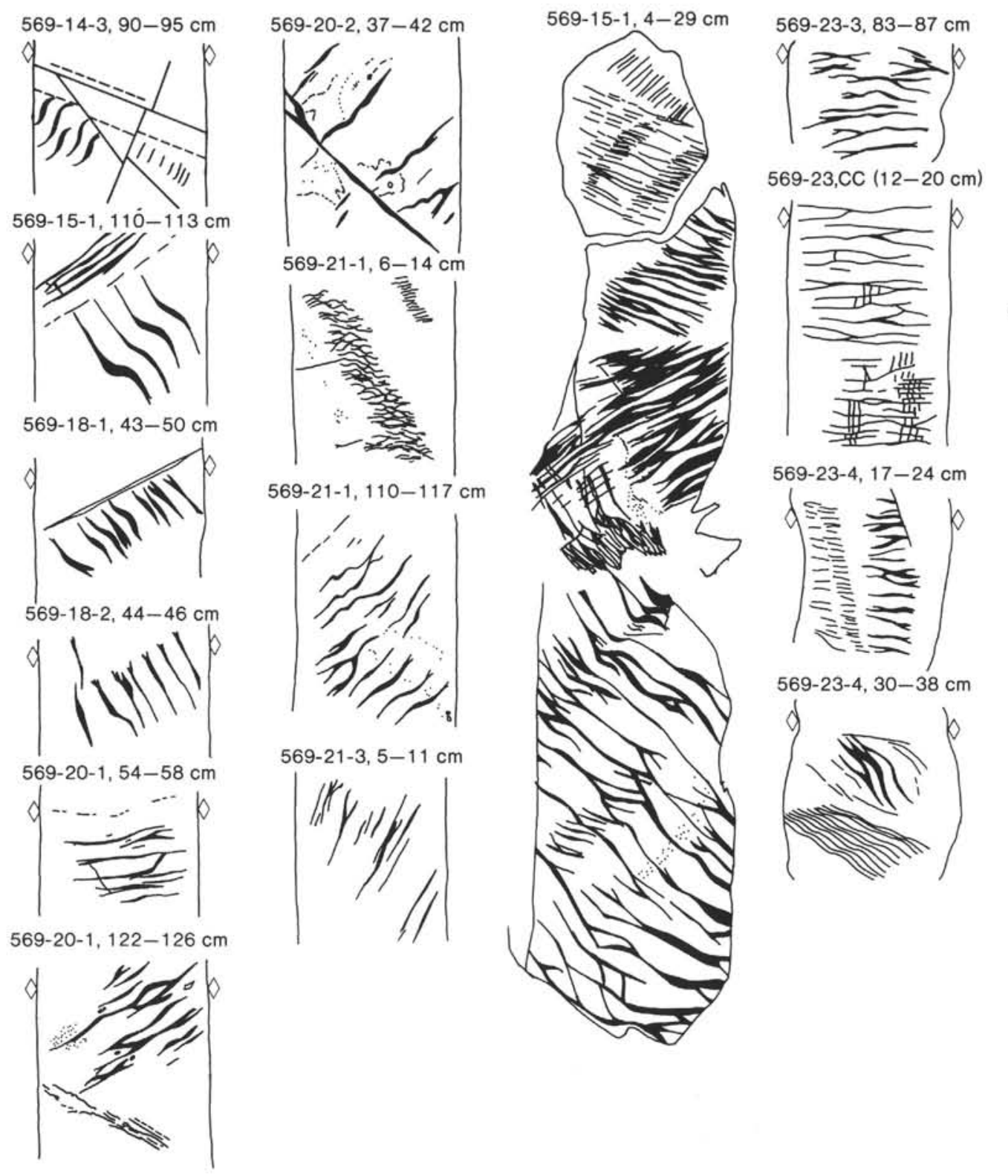

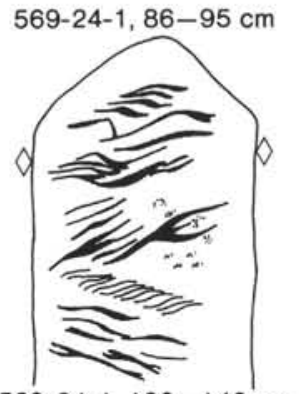

569-24-1, 100-140 cm

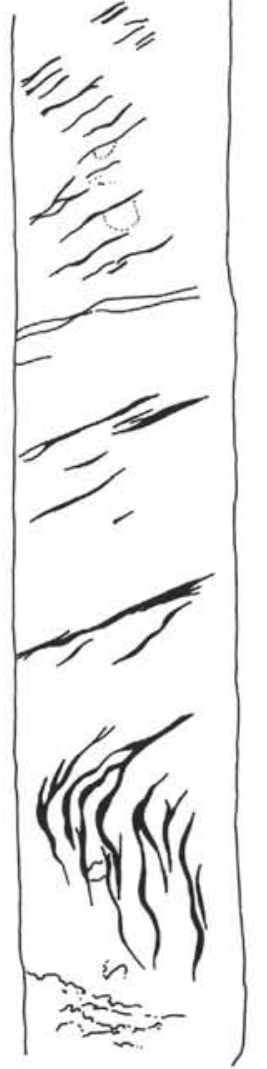

$569-24-3,101-112 \mathrm{~cm}$

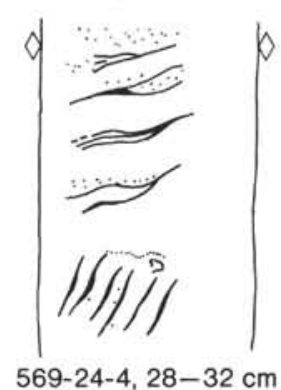

$569-24-4,28-32 \mathrm{~cm}$

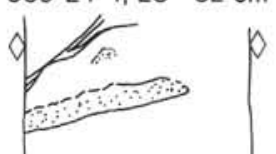

$569-24-4,58-67 \mathrm{~cm}$

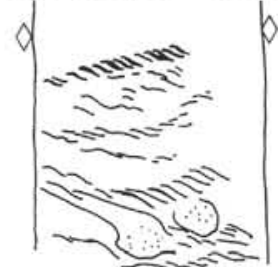

$569-25-3,48-56 \mathrm{~cm}$

$$
\left.\right|_{\frac{\pi}{2}} ^{\frac{z^{2}}{5}}
$$

569-26-1, 88-100 cm

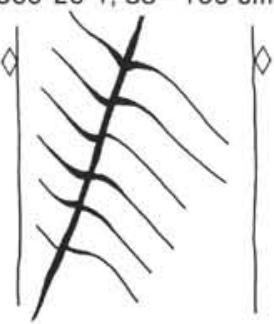

$569 \mathrm{~A}-1-1,95-105 \mathrm{~cm}$

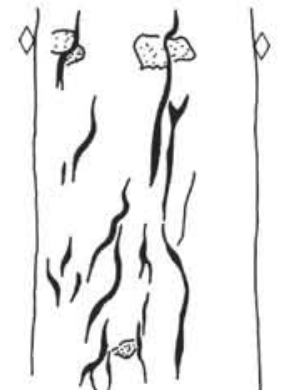

569A-1-4, 108-129 cm

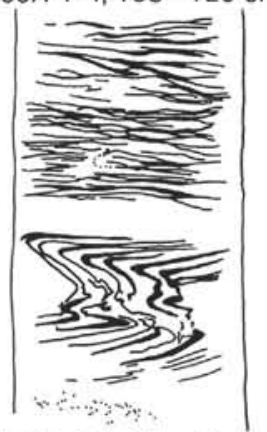

569A-2-1, 15-18 cm

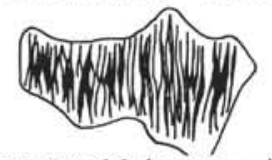

$569 \mathrm{~A}-2, \mathrm{CC}(5-22 \mathrm{~cm})$

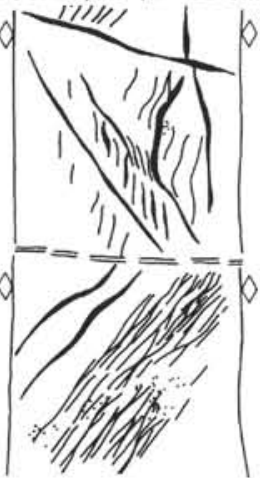

${ }^{3}$ Dotted part is sandy or calcareous. The marks beside the cores indicate horizontal traces caused by drilling. Core width averages about $6 \mathrm{~cm}$. 


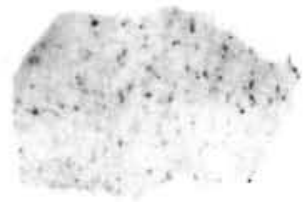

1
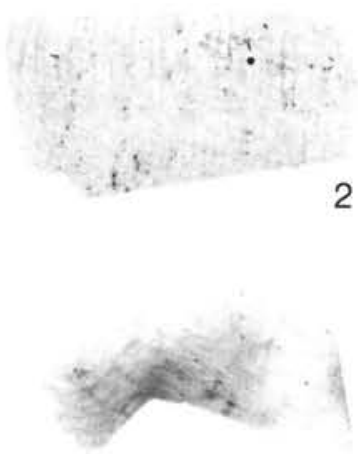

10

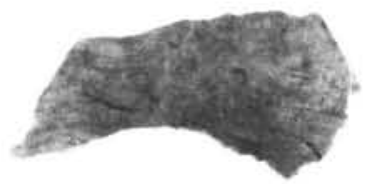

11

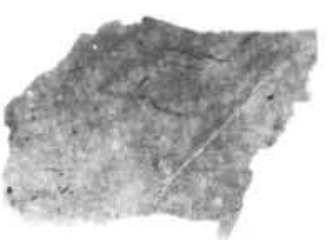

12

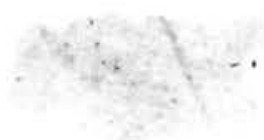

13

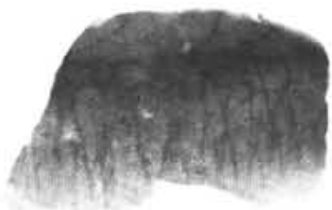

14

\section{3}
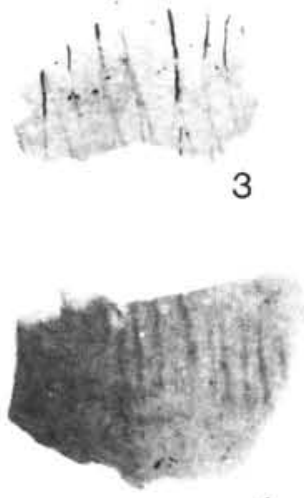

4
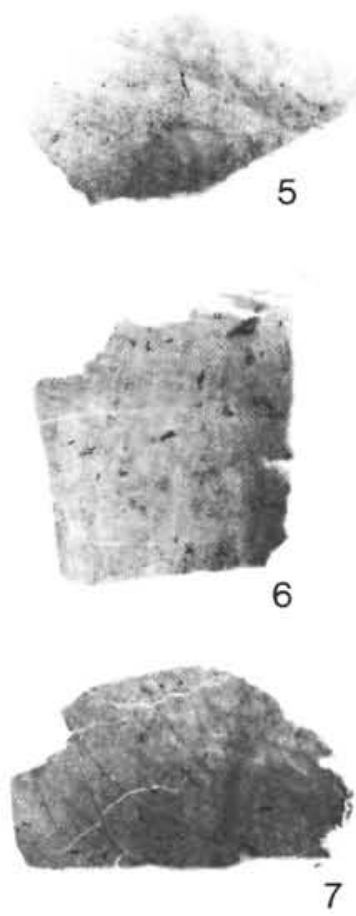

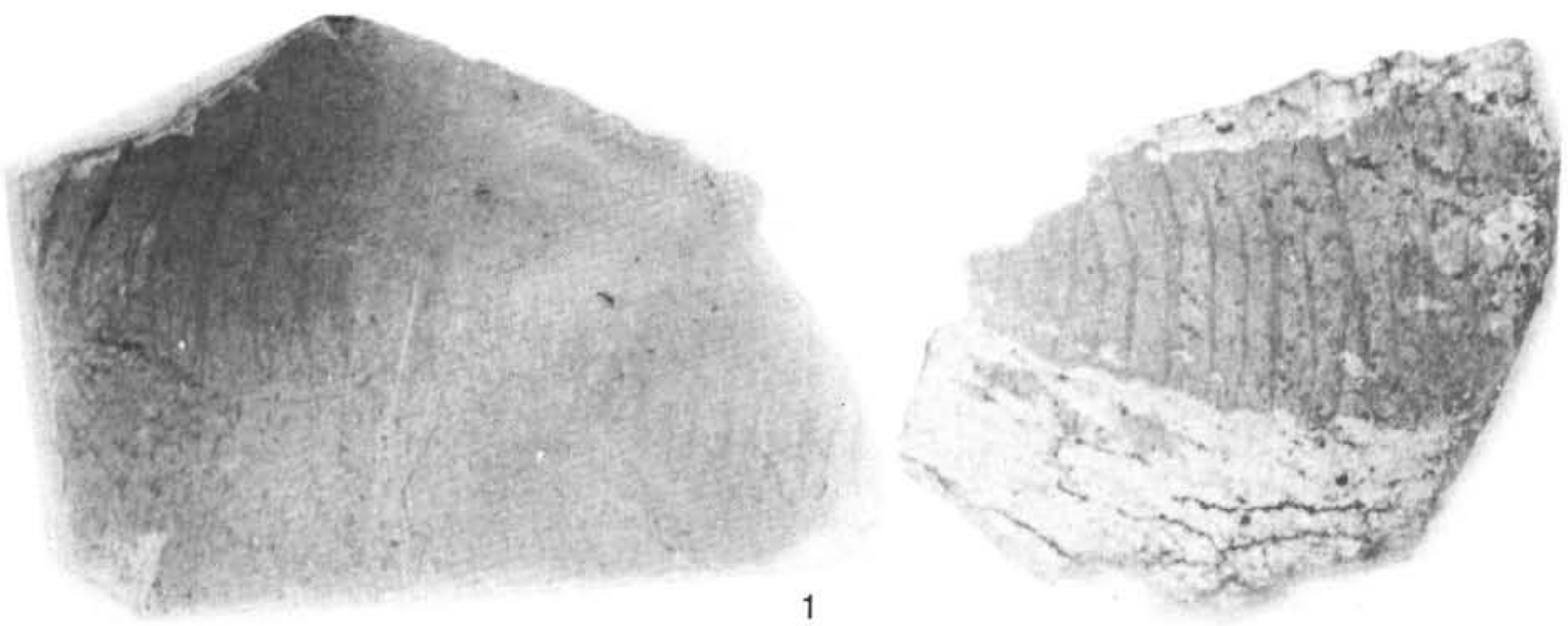

2
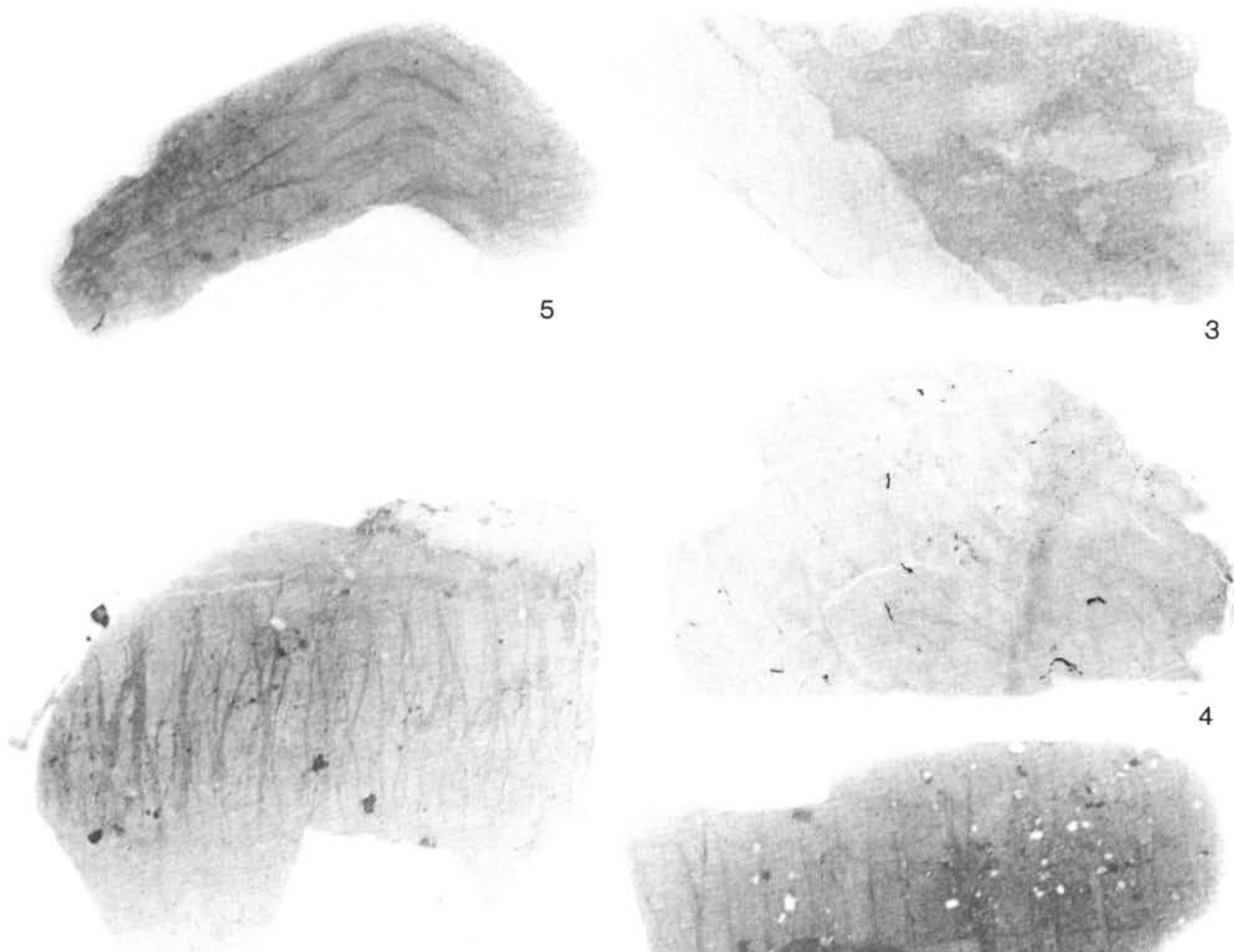

6
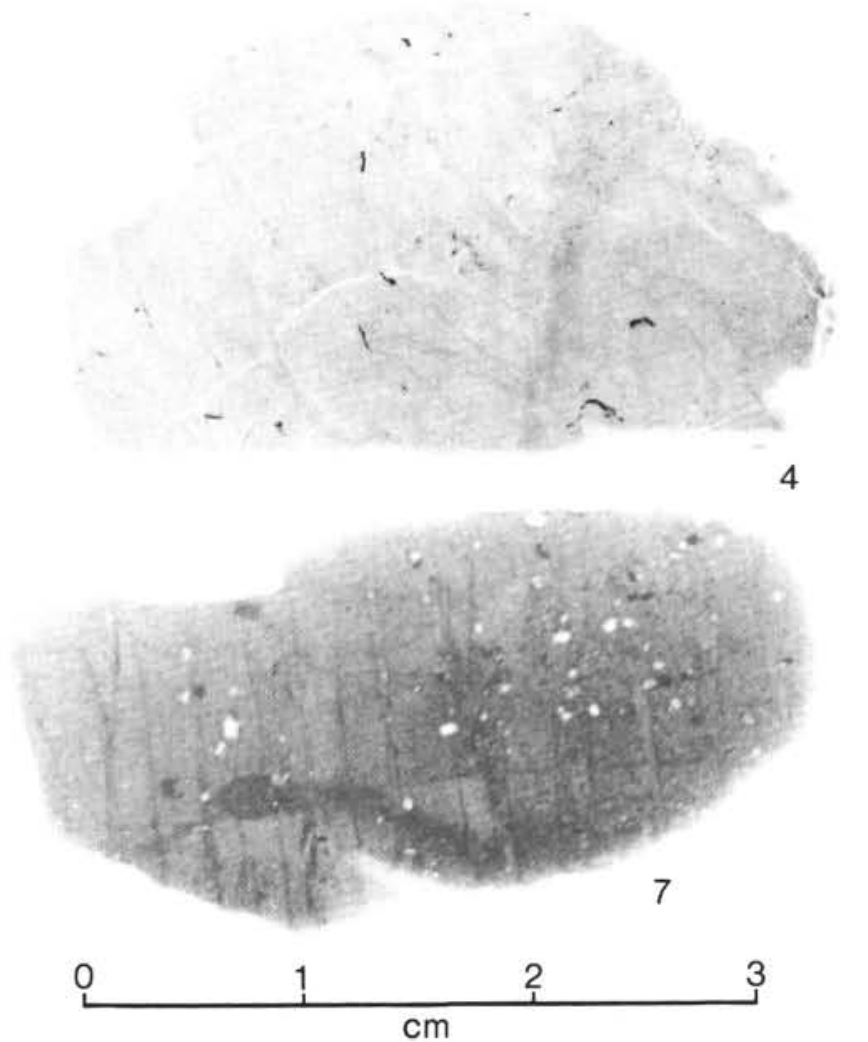

Plate 2. Photographs of vein structure under reflected light. Compare these photographs to the x-ray radiographs in Plate 1. 1. Sample 568-42-7, 22-26 cm. 2. Sample 569-17-3, 122-124 cm. 3. Sample 569-20-1, 43-44 cm. 4. Sample 569-26-1, 82-84 cm. 5. Sample 569A-1-3, 130-132 $\mathrm{cm}$. 6, 7. For comparison, Miocene Miura Group at Setogawa, Boso Peninsula and at Chiyogasaki, Miura Peninsula. 

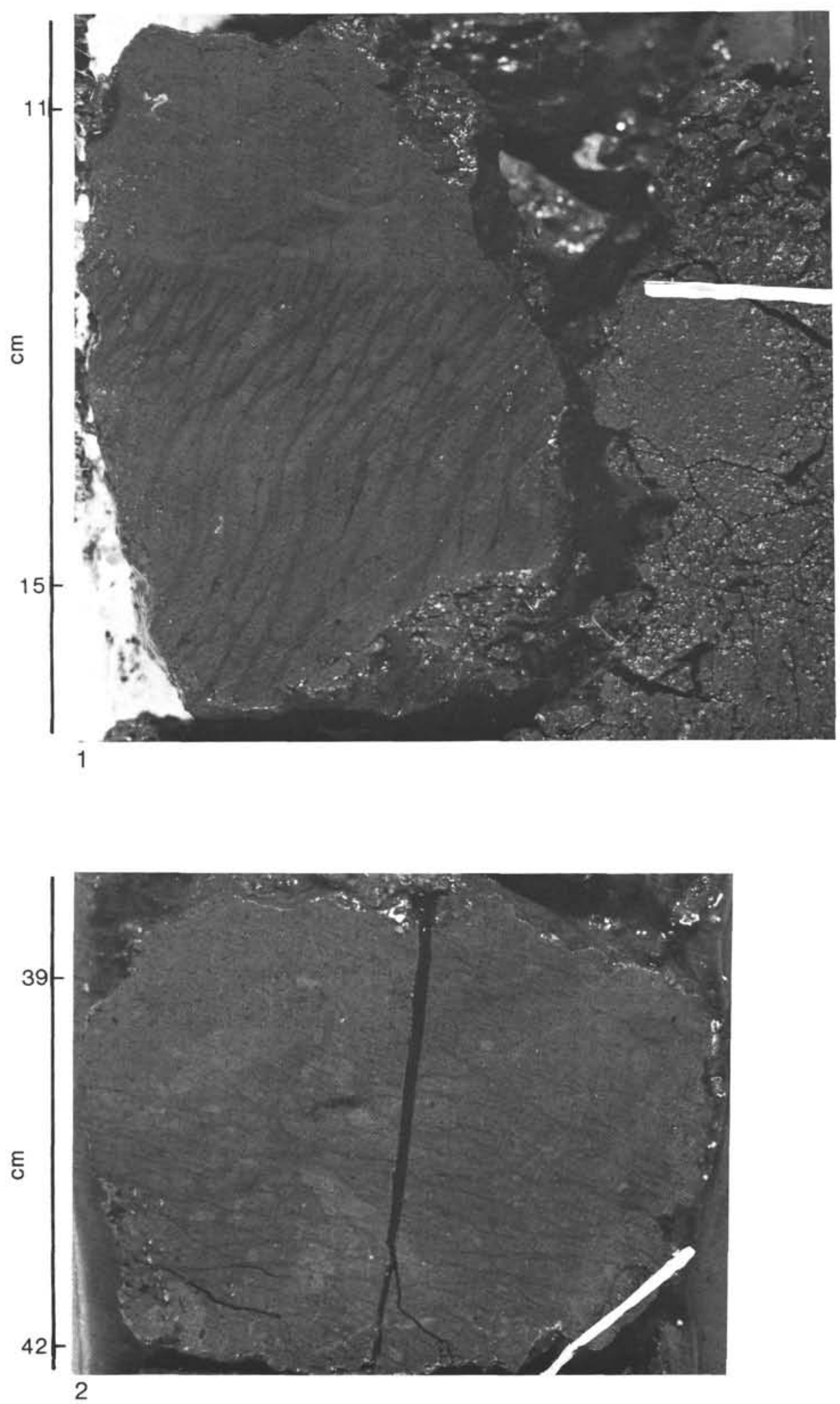

Plate 3. 1. Braided type of veins Sample $569-17-1,10-17 \mathrm{~cm}$. 2. Anastomosing type of veins, Sample $568-32-1,37-42 \mathrm{~cm}$. Bedding trace shown by white line; $\mathrm{cm}$ scale is on the left. 

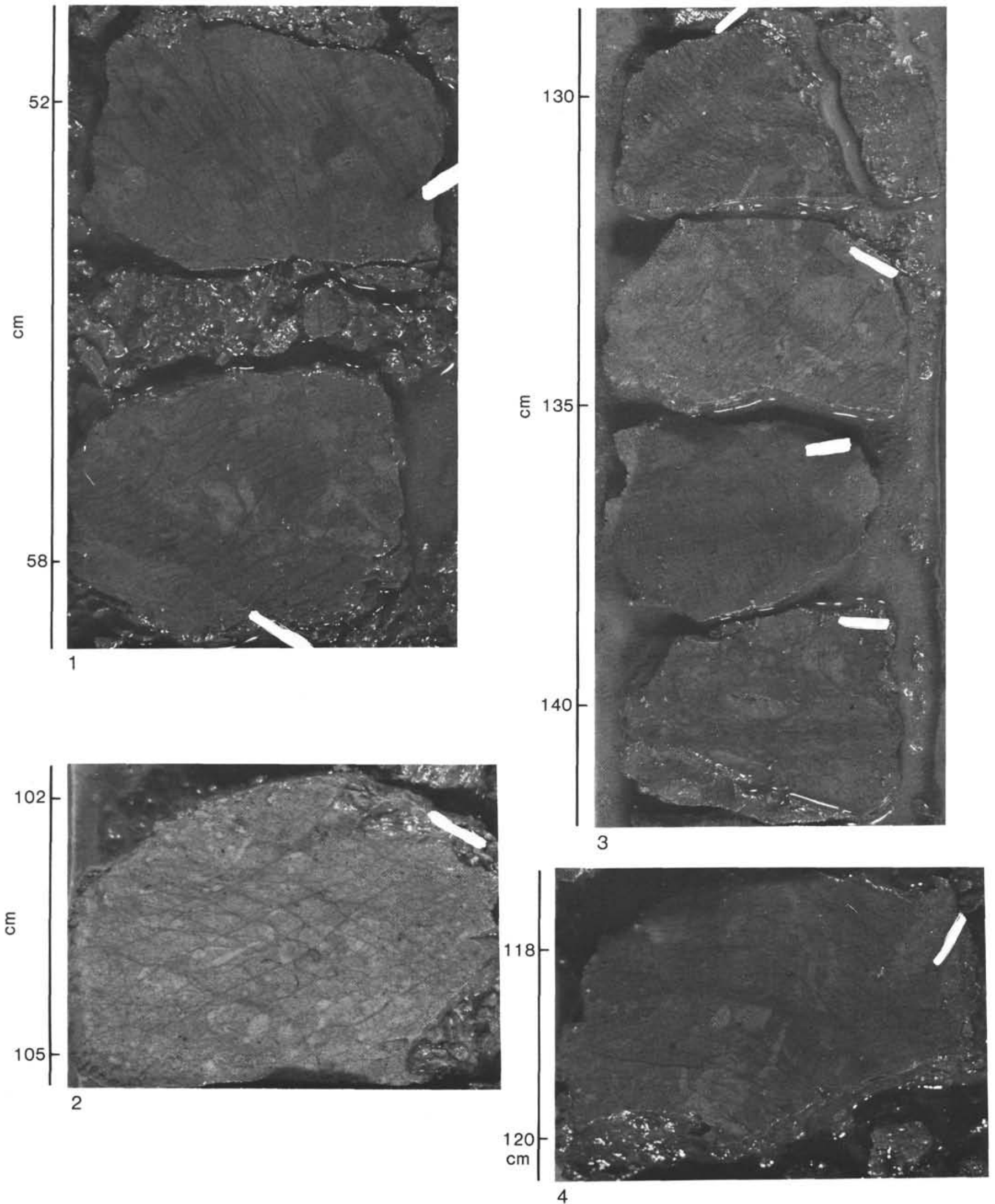

Plate 4. Examples of veins cutting around or avoiding the calcareous or sandy spots, mostly of burrows. 1. Sample 568-28-4, 51-59 cm. 2 . Sample 568-29-1, 102-106 cm. 3. Sample 568-30-2, 128-143 cm. 4. Sample 568-32-3, 116-121 cm. Bedding trace shown by white line; cm scale is on the left. 

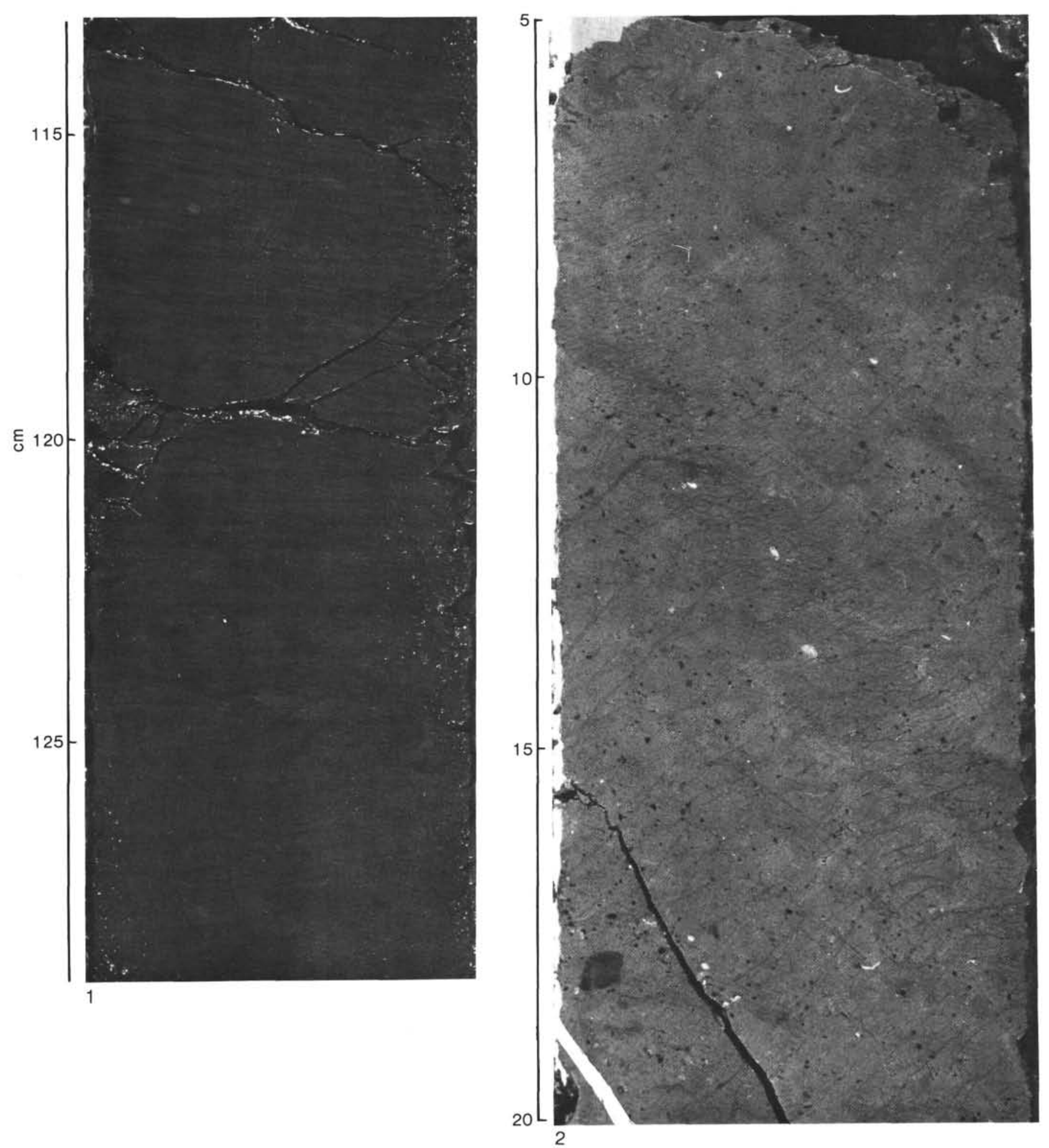

Plate 5. 1. Parallel type of veins, Sample $569 \mathrm{~A}-1-4,113-128 \mathrm{~cm}$. 2. Closely spaced veins rotated in downslope fashion, Sample 569-21-1, 5-20 cm. Bedding trace in 1. is not known; in 2., bedding trace is by white line. Centimeter scale is on the left. 
VEIN STRUCTURE
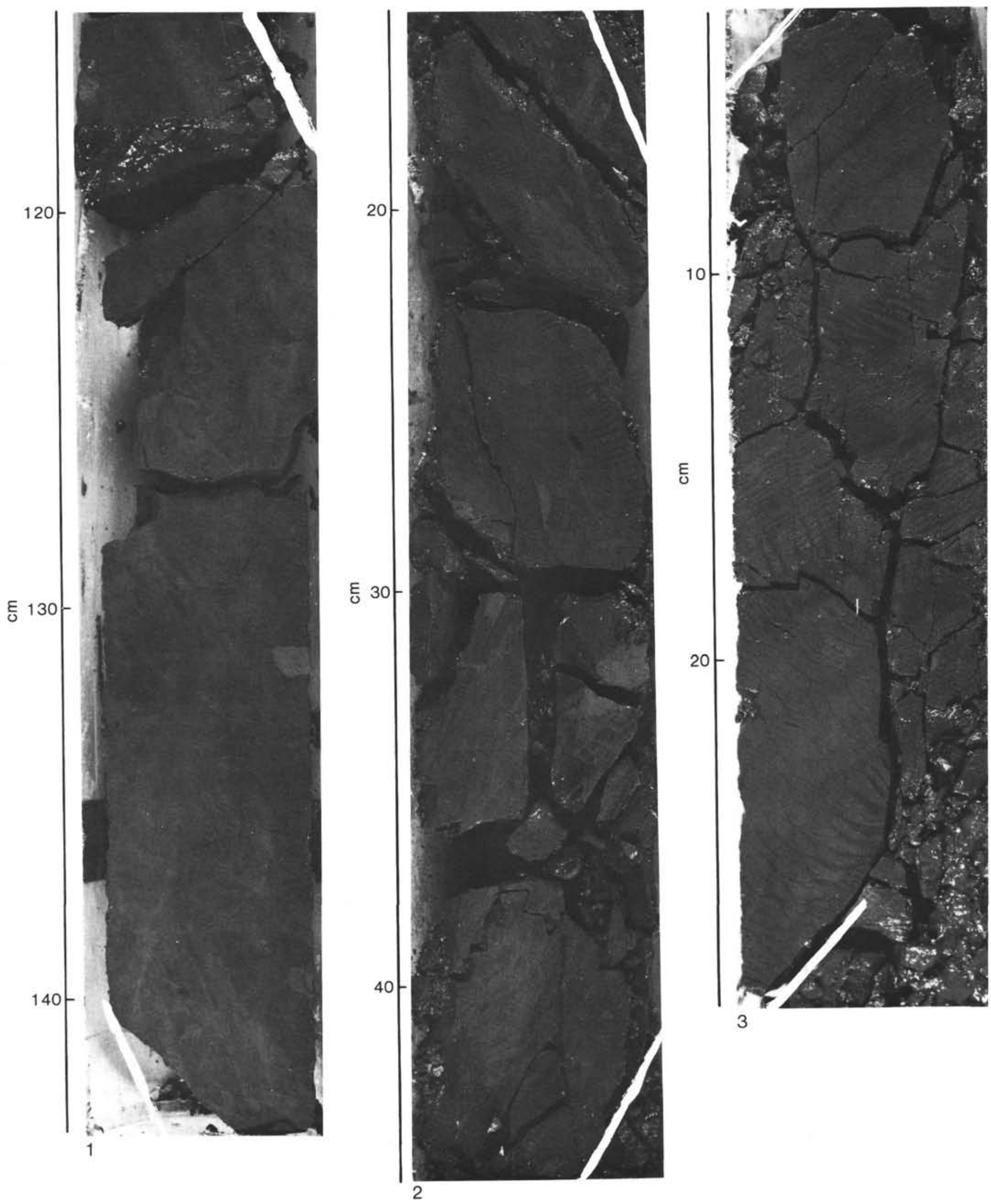

3

Plate 6. Examples of long cores having many kinds of vein structures. 1. Sample 568-42-6, 116-143 cm. 2. Sample 568-42-7, 16-43 cm. 3. Sample $569-15-1,5-28 \mathrm{~cm}$. Bedding trace is shown by white line; $\mathrm{cm}$ scale is on the left. 